Records of the Australian Museum (1995) Vol. 47: 141-160. ISSN 0067-1975

\title{
Notes on Australian Zodariidae (Araneae), II. Redescriptions and New Records
}

\author{
RUDY JOCQUÉ \\ Koninklijk Museum voor Midden-Afrika, B-3080 Tervuren, Belgium \\ rjocque@vub.ac.be
}

\begin{abstract}
The species of Australian Zodariidae that were described prior to Jocqué (1991) are listed and those of which the identity could be traced are redescribed. Neostorena vituperata and Nostera nadgee $(\sigma,+)$ are described as new and Nostera is widened to accommodate Nostera leucosema (Rainbow) n. comb. Other new combinations are Habronestes grimwadei (Dunn), Habronestes macedonensis (Hogg), Habronestes toddi (Hickman), Storosa tetrica (Simon), Neostorena torosa (Simon), Neostorena spirafera (Koch) and Mallinella zebra (Thorell). The species Hetaerica aresca and $H$. variegata and the genus Hetaerica are invalidated. New records for a number of recently described species are provided.
\end{abstract}

JoCQUÉ, RUDY, 1995. Notes on Australian Zodariidae (Araneae), II. Redescriptions and new records. Records of the Australian Museum 47(2): 141-160.

In this second of two papers clarifying the confused taxonomy of Australian Zodariidae, all known Australian species that were not treated in Jocqué (1991), Jocqué \& Baehr (1992) or Jocqué (1995) are redescribed. New distributional data on these species and some of the recently described species are added. Some species mentioned in the catalogue of Davies (1985) (see Table 1) are considered "species inquirendae" either because the combination of an insufficient initial description and loss of types, or the description of juveniles, makes it impossible to diagnose the taxon. A key to the genera is provided in Jocqué (1995).

\section{Methods}

The methods and format are similar to those used by Jocqué \& Baehr (1992). All measurements are in millimetres.

\begin{abstract}
Abbreviations are given in Jocqué (1995, p. 118, this issue). Museums and other institutions are abbreviated as follows: AM-Australian Museum, Sydney (M. Gray); AMNH-American Museum of Natural History, New York (N. Platnick); BMNH-Natural History Museum, London (P. Hillyard); CAS-California Academy of Sciences (W. Pulawski \& D. Ubick); KBIN-Koninklijk Belgish Instituut voor Natuurwetenschappen, Brussels (L. Baert); MCSNG-Museo Civico di Storia naturale, Genoa (G. Doria); MCZ-Museum of Comparative Zoology, Cambridge (H. Levi); MNHN-Musée national d'Histoire naturelle, Paris (J. Heurtault \& C. Rollard); NVM-Victoria Museum, Melbourne (M. Harvey); NRS-Naturhistoriska Riksmusset, Stockholm (T. Kronestedt); QM-Queensland Museum, Brisbane (R. Raven); RMNH-Rijksmuseum van Natuurlijke Historie, Leiden (P. Van Helsdingen); SAMA - South Australian Museum Adelaide (D. Hirst); UMO-University Museum,
\end{abstract}



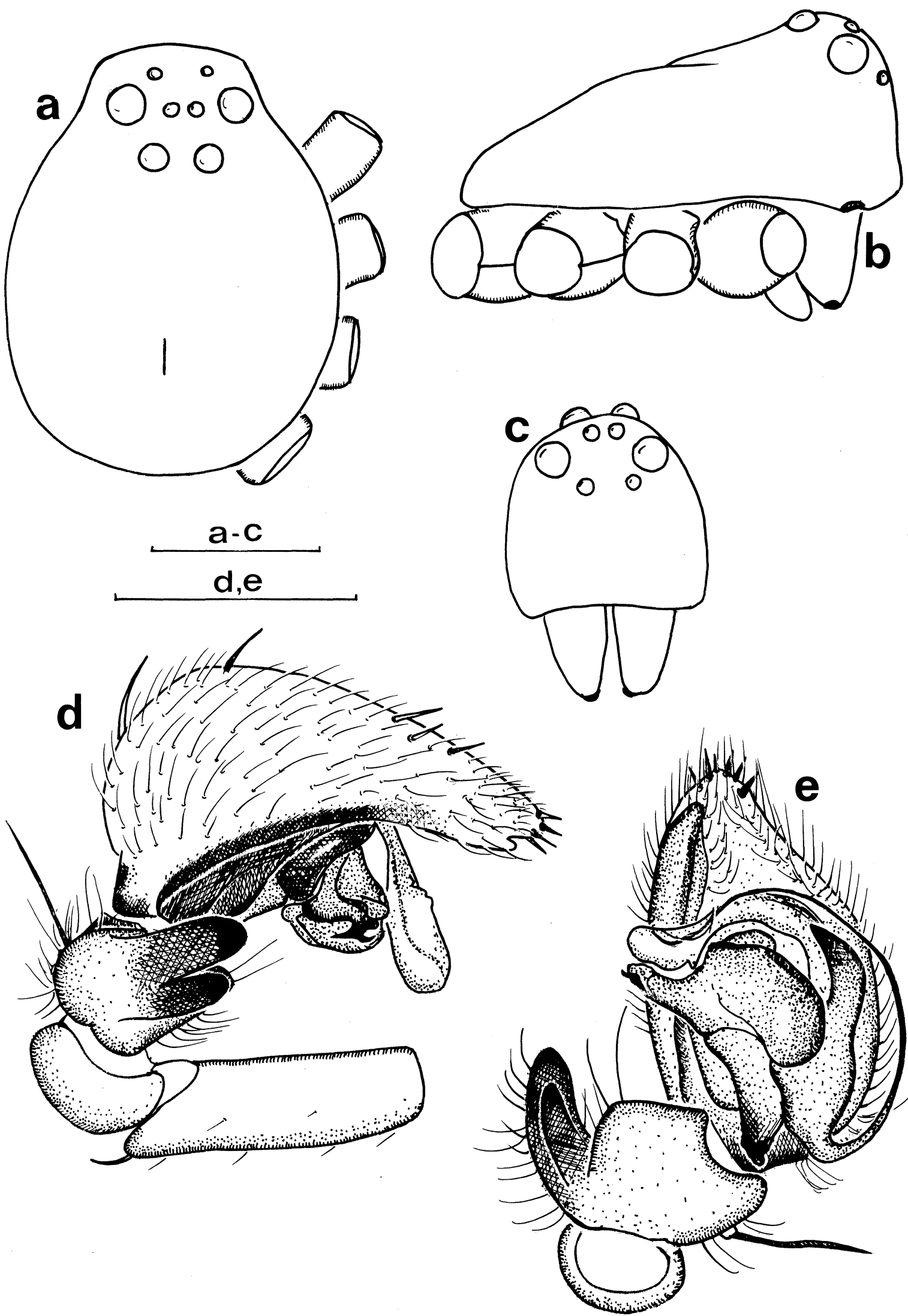

Fig. 1. Habronestes australiensis (Pickard-Cambridge) a, carapace, dorsal view; b, carapace, lateral view; c, carapace, frontal view, d, male palp, lateral view, e, male palp, ventral view. Scales $1 \mathrm{~mm}$. 
Hope Entomology Collections, Oxford (J. Lansbury); WAM-Western Australian Museum, Perth (M. Harvey); ZMB-Zoologisches Museum, Berlin (M. Moritz); $\mathrm{ZMH}$-Zoologisches Museum, Hamburg (G. Rack).

\section{Taxonomy}

\section{Habronestes Koch}

\section{Habronestes australiensis (Pickard-Cambridge)}

Fig. 1a-e

Storena australiensis Pickard-Cambridge, 1869: 58 (description of $\sigma^{\prime}$ ).-Rainbow, 1911: 149 .

Habronestes austrialensis [sic].-Koch, 1872: 302, 307 (description of $\sigma$ ).

Remarks. The type specimen has been dried and pinned at one stage. All legs are detached and it is therefore impossible to check the unusual formula of leg lengths (4231) as given by Pickard-Cambridge (1869). Koch (1872: 307) mentions: "Ich habe diese ausgezeignete Spinne nach vielem Bedenken zu dem Genus Storena Walck. gerechnet". In the same paper, however, he introduces the new combination $H$. australiensis (austrialensis [sic] is an obvious lapsus) which now appears to be correct. The male palp has the typical conformation, diagnostic of the genus that is the Yshaped tegulum.

Type material. Holotype $\sigma:$ Australia (UMO 126, examined).

Diagnosis. The male of this species is recognised by the two lateral tibial apophyses of the palp, both broadly rounded at the tip; the large membranous tegular apophysis is equally characteristic.

\section{Description}

Male. Total length $5.00 \mathrm{~mm}$; carapace $2.54 \mathrm{~mm}$ long, $1.96 \mathrm{~mm}$ wide.

Colour: chitinised parts virtually uniform medium brown except femora of anterior leg pairs which are orange in the proximal half.

Eyes: Fig. 1a-c. Clypeus $0.63 \mathrm{~mm}$ high.

Leg formula as given by Pickard-Cambridge (1869) probably wrong. Some of the legs with numerous long spines. Hinged hairs present. Six spinnerets.

Male palp (Fig. 1d,e): tibia with two lateral apophyses, the inferior one shorter and narrower than the superior one; both rounded at extremity. Cymbial fold short; curved sclerotised part of tegular "Y" short and pointed at extremity; tegular apophysis membranous, large, widened toward extremity and pointing downward.
Female. Unknown.

Distribution. Imprecise; the holotype, the only known specimen, is from "Australia".

\section{Habronestes bradleyi (Pickard-Cambridge)}

Fig. 2a,b

Storena bradleyi Pickard-Cambridge, 1869: 55, table IV, figs 12-20 (description of $\sigma^{\prime}$ ).

Habronestes bradleyi.-Koch, 1872: 305 (description of $\sigma^{\prime}$ ). Storena ?bradleyi.-Kritscher, 1956: 246 (description of ${ }^{\text {) }}$.

Type material. LECTOTYPE $\sigma$ (by present designation): Australia, New South Wales, Sydney, Bradley (UMO) (examined). PARALectotypes: $1 \sigma, 1$ juvenile (together with lectotype).

Other material examined. One $\sigma$, Victoria, Tallarook, 25 September 1977, on ground, H. Parnaby (AM KS20238).

Diagnosis. The male of $H$. bradleyi is easily recognised by the presence of numerous spatulate hairs on the ventral side of Mt I. Both sexes are recognised by the small eyes of the anterior row as compared to those of the second row.

\section{Description}

Male. Total length $4.80 \mathrm{~mm}$; carapace $2.42 \mathrm{~mm}$ long, $1.92 \mathrm{~mm}$ wide.

Colour. The specimens of the type series are apparently strongly bleached; carapace uniform pale brown; chelicerae and sternum brownish yellow, legs brown to yellow, darkened towards the femora; trochanters pale yellow; abdomen dark grey with white dots on dorsum; a long oval pale patch on either side.

Eyes in anterior row small as compared to those of second row; AME less than their radius apart and with a diameter of $0.07 \mathrm{~mm}$; ALE 3 times their diameter apart and slightly smaller $(0.06 \mathrm{~mm})$ than AME; PME twice as large as ALE and about their diameter apart; PLE twice as large as AME and 2.5 times their diameter apart. $\mathrm{MOQ}, \mathrm{AW}=0.5 \times \mathrm{PW}$; AW $=0.5 \times \mathrm{L}$. Clypeus straight; $0.62 \mathrm{~mm}$ high or about 10 times the diameter of an ALE.

Legs: measurements and spination are given in Tables 2 and 3.

Male palp, see Fig. 2a,b.

Female. See Kritscher's (1956) description.

Distribution. South-eastern Australian mainland. 

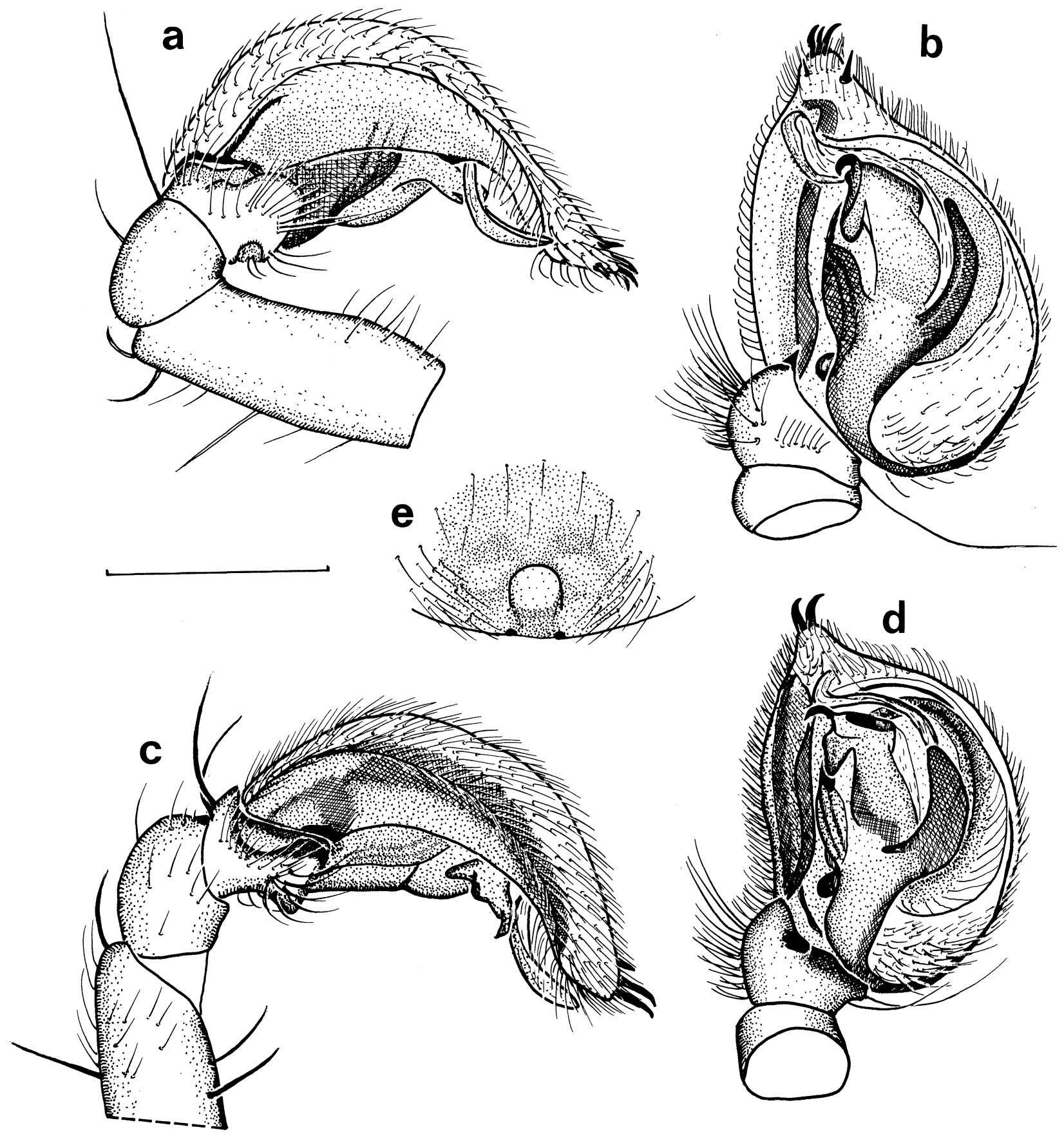

Fig. 2. Habronestes bradleyi (Pickard-Cambridge) a, male palp, lateral view; b, ventral view. Habronestes grimwadei (Dunn) c, male palp, lateral view, d, male palp, ventral view, e, epigyne. Scale $1 \mathrm{~mm}$.

Habronestes grimwadei (Dunn) n.comb.

Fig. 2c-e

Storena grimwadei Dunn, 1951: 11, figs 1-4 (descriptions of $\sigma$ and $\odot$ ).

Type material. HOLOTYPE $\sigma$ : Australia, Western Australia, about 40 miles west of Eucla, $31^{\circ} 43^{\prime} \mathrm{S}, 128^{\circ} 53^{\prime} \mathrm{E}, 30$ August
1947, preying on Iridomyrmex sp., R. Pescott (NVM) (examined). PARATYPES: 2 우, together with holotype (examined).

Other material examined. QUEENSLAND: $5 \sigma^{\circ} \sigma, 3 \%+$, Mulgowie, Lardly Valley, 21 January 1981, Eucalyptus woodland, M. Grant (QM S3719); 10, 1\%: same data as previous (KBIN); $20 \sigma$, Mulgowie, September-November 1981, M. Grant (QM S3720); $2 \sigma^{\circ} \sigma^{\circ}$, same data as previous, 
5 May 1981 (QM S3718); Windermere Station, Brigalow, $27^{\circ} 25^{\prime} \mathrm{S}, 149^{\circ} 41^{\prime} \mathrm{E}, 5$ December 1987, R. Raven (QM S2480); 1\%, SCQ, Ambathala, 9 May 1979, K.M. Donald (QM S4460). VICTORIA: 1 ?, $8.3 \mathrm{~km}$ east of confluence of Lindsay River and Mullaroo Creek, $34^{\circ} 11^{\prime} \mathrm{S} 141^{\circ} 10^{\prime} \mathrm{E}$, site 103, pitfall, November 1985, A Yen (NVM); $20^{\circ} 0^{\circ}, 6.7 \mathrm{~km} \mathrm{SSW} \mathrm{of}$ junction MV highway and Annuello Road, 34 $51^{\prime} \mathrm{S} 42^{\circ} 36^{\prime} \mathrm{E}$, pitfall, January 1986, A Yen (NVM); 10, same data as previous but October 1985; 1 , Bacchus Marsh, 10 October 1974, V. Salinitri (NVM); SouTH Australia: 10', Munyaroo Conservation Park, $8 \mathrm{~km}$ SW Moonabie Homestead, 33ำ' $19^{\prime} \mathrm{S}$ 137 12'30"E, 28 April 1991, pitfall, Head \& Jansen (SAMA N199279); WeSTERN AUSTRALIA: 10', Tenterden, 7 February 1969, H. Osburne (AM KS15636); 1 으, near Weebubbie Cave, 30 December 1971, cave, M. Gray (AM KS15619). NEW SOUTH WALES: $2 \sigma^{\circ} \sigma$, Mount Lambie, 13 November 1988, G.S. Hunt (AM KS29940); 10', Bungonia Caves area, near information centre, November 1989, G. Hunt (AM KS22566); 10 , Armidale, running on rock "Warrana", September 1978, K. Jacques (QM S3849); 1 6 , Kowar Forest, ACT, 12 September 1985 (QM S4383).

Diagnosis. The species has a characteristic colour pattern: a bright orange carapace with contrasting dark sepia abdomen with white dots. The male is recognised by the palpal tibia with deep lateral concavity whereas the female has a typical epigyne with central concavity. The species is also remarkable by having leg II slightly longer than leg I. The species is closely related to $H$. bradleyi with which it shares the modified hairs on the anterior Mt.

\section{Description}

Male. Total length $4.17 \mathrm{~mm}$; carapace $2.29 \mathrm{~mm}$ long, $1.75 \mathrm{~mm}$ wide.

Colour. Carapace bright orange with a large darker $\mathrm{V}$ in front of fovea and faint radiating striae; in eye region with bluish metallic lustre; chelicerae and legs, yellowish orange, metatarsi and tarsi paler; sternum brownish orange. Abdomen dark sepia in front with a white collar interrupted in the middle; a white spot on each side just behind the middle and two small ones just in front of the spinnerets. Remainder dark sepia.

Carapace profile evenly rounded, reaching highest point halfway between fovea and eyes.

Eyes: both rows strongly procurved thus giving the impression of four levels; a, 0.07; b, 0.06; c, 0.08; d, $0.11 ; \mathrm{e}, 0.05 ; \mathrm{f}, 0.06 ; \mathrm{g}, 0.15 ; \mathrm{h}, 0.13$. MOQ, AW = $0.63 \times \mathrm{PW} ; \mathrm{AW}=0.53 \times \mathrm{L}$.

Legs: measurements and spination are given in Tables 2 and 3. Anterior legs with short modified ventral setae on metatarsi and distal half of tibiae.

Male palp (Fig. 2c,d): tibia with double lateral keel, delimiting a rather wide lateral concavity; bulbus typical for genus with hook-shaped tegular apophysis and long and narrow subtegular membrane.

Female. Total length $5.42 \mathrm{~mm}$; carapace $2.83 \mathrm{~mm}$ long, $2.04 \mathrm{~mm}$ wide.

Colour as in male.
Eyes as in male.

Relative length and spination of legs as in male but Mt I and T I without modified ventral setae.

Epigyne (Fig. 2e): with roughly quadrangular central concavity. The appearance of the epigyne varies greatly with the angle at which it is viewed.

Variation. There is considerable variability in the number and position of the white spots on the abdomen. In front of the pair of white dorsal spots there may be second pair of smaller white spots, whereas in some specimens the white spots are reduced to tiny points.

Distribution. Western Australia, Victoria, New South Wales and Queensland.

\section{Habronestes macedonensis (Hogg) n.comb.}

Fig. $3 \mathrm{c}, \mathrm{d}$

Storena macedonensis Hogg, 1900: 2, 97, 98.-Rainbow, 1911: 150.

Type material. HOLOTYPE $\sigma$ : Australia, Victoria, Macedon (BMNH 1907.2.24.38) (examined).

Diagnosis. The male of this species is recognised by the two short, pointed tibial apophyses; the lateral one provided with a short rounded dorsal lamella; the ventral one short and pointed. The presence of a distal whorl of six short spines on F III and F IV is also characteristic.

\section{Description}

Male. Total length $5.67 \mathrm{~mm}$; carapace $2.98 \mathrm{~mm}$ long, $2.21 \mathrm{~mm}$ wide.

Colour. Carapace medium brown with some darker markings radiating from fovea; legs medium brown with white rings (precise pattern not clear as all legs are detached at least from patella onwards). Dorsum of abdomen sepia with two rows of white spots in front, followed by a median triangle and a longitudinal spot in front of spinnerets; sides almost entirely white; venter pale brown, darker in front of spinnerets.

Eyes: $a, 0.21 ; \mathrm{b}, 0.13 ; \mathrm{c}, 0.15 ; \mathrm{d}, 0.15$; e, 0.05 ; , $0.06 ; \mathrm{g}, 0.11 ; \mathrm{h}, 0.18$. MOQ, $\mathrm{AW}=1.14 \times \mathrm{W} ; \mathrm{AW}=$ $0.94 \times$ L. Clypeus straight: $0.56 \mathrm{~mm}$ high or about 4.3 times width of ALE.

Legs: measurements of femora I 2.60; II 2.47; III 2.34; IV 2.81. Spination of femur: I $p l 1 d 3^{*}$; II $p l 1 d 3^{*} r l 1$; III $p l 2 * d 3 * r l 3 * d w 6$; IV $p l 1 d 3 * d w 6$.

Male palp (Fig. 3c,d): tibia with two apophyses: a short, pointed lateral one provided with a short rounded dorsal lamella and a pointed ventral one.

Female. Unknown.

Distribution. Known only from the type locality, Macedon, Victoria. 

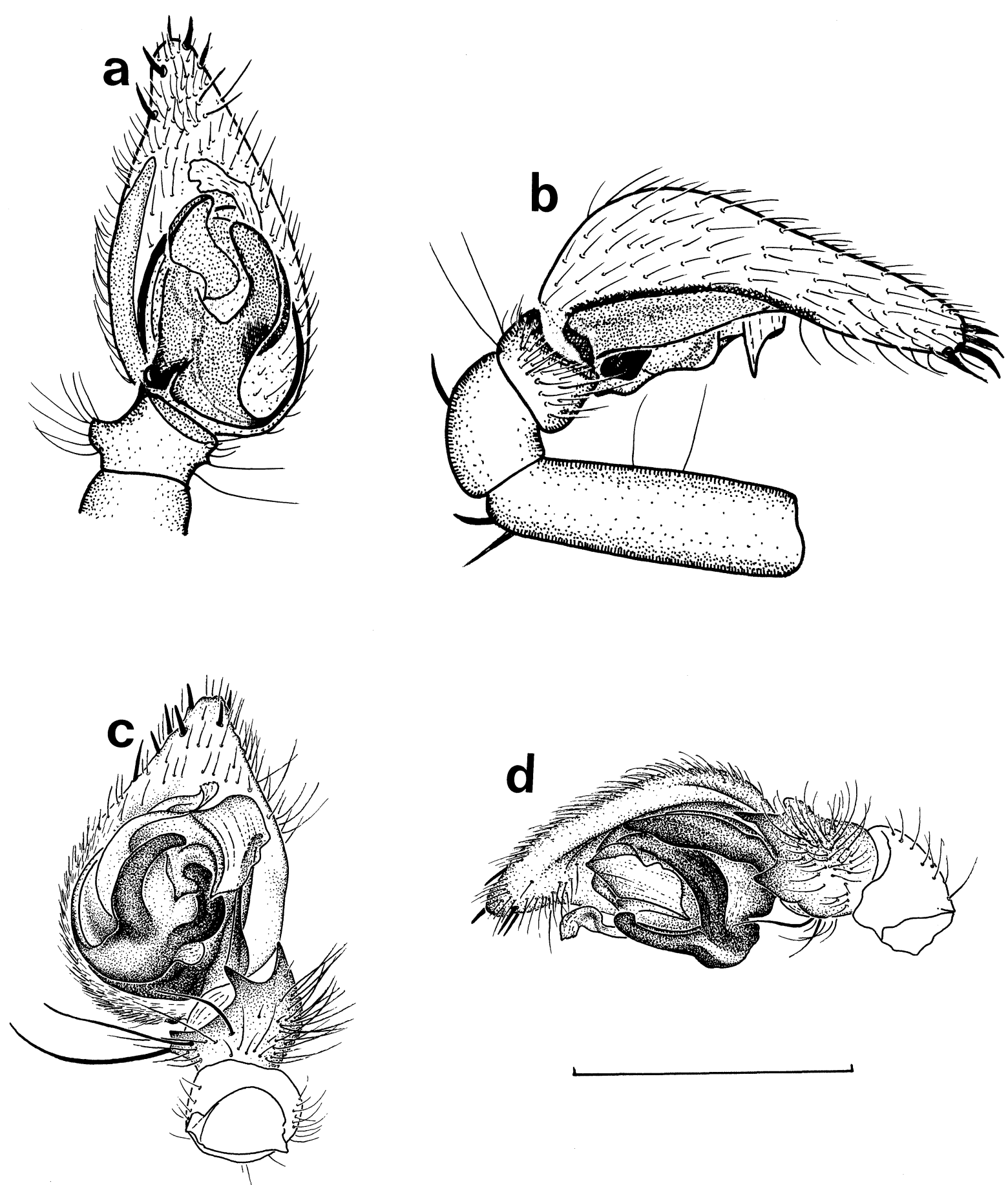

Fig. 3. Habronestes toddi (Hickman) a, male palp, ventral view, b, male palp, lateral view. Habronestes macedonensis (Hogg) c, male palp, ventral view, d, male palp, lateral view. Scale $1 \mathrm{~mm}$.

\section{Habronestes toddi (Hickman) n.comb.}

Fig. 3a,b

Storena toddi Hickman, 1944: 38 (description of $\sigma^{\prime}$ ).

Type material. HOLOTYPE $\sigma$ : Australia, Northern Territory, c. $24^{\circ} \mathrm{S} 136^{\circ} \mathrm{E}, 6$ miles north of junction of Todd and Hale
Rivers, Simpson Desert Expedition, coll. 540 (AM KS6686) (examined). The type specimen is in bad condition, the carapace and abdomen are shrunk, apparently due to drying.

Diagnosis. The male of this species is easily recognised by the denticles on the ventral side of $\mathrm{T} \mathrm{I}$ and Mt I, by the absence of a weel defined tibial apophysis on the palp and by the elongate cymbium. 


\section{Description}

Male. Total length $3.33 \mathrm{~mm}$; carapace $1.96 \mathrm{~mm}$ long, width not measured.

Colour. Carapace pale yellow in thoracic area, yellowish brown on cephalic area; chelicerae as cephalic area; sternum and legs pale yellow. Abdomen grey with white spots: two rather large ones and finally a fourth pair of small one; a large single patch in front of spinnerets. Sides with a longitudinal white patch; venter pale grey.

Eyes: a, 0.17; b, 0.11; c, 0.09; d, 0.12; e, 0.05; f, $0.04 ; \mathrm{g}, 0.15 ; \mathrm{h}, 0.15$. MOQ, $\mathrm{AW}=1.17 \times \mathrm{W} ; \mathrm{AW}=$ $0.95 \times$ L. Clypeus straight: $0.53 \mathrm{~mm}$ high or 4.82 times width of ALE.

Legs: measurements and spination are given in Tables 2 and 3. T I and proximal half of Mt I with numerous short ventral denticles.

Male palp (Fig. 3a,b): tibia with a lateral ridge bearing some setae but without a well pronounced apophysis; cymbium elongate; tegulum typically Yshaped.

Female. Unknown.

Distribution. Known only from the type locality in central Australia.

\section{Habronestes striatipes Koch}

Habronestes striatipes Koch, 1872: 313, pl XXV, fig. 4 (description of $\%$ ).-Butler, 1876: 353.

Storena striatipes.-Simon, 1893: 427.-Hogg, 1900: 72.Rainbow, 1911: 151.-Rainbow, 1912: 191.-Jocqué, 1991: 57 (descriptions of $\sigma$ and $\%$ ).

Material examined. QUEENSLAND: $10^{\circ}, 7 \% \circ$, Rundle Range, 24-31 March 1975, RK VED (QM 3684).

Distribution. Coastal areas of Queensland.

\section{Storosa Jocqué}

Storosa tetrica (Simon) n.comb.

Fig. $4 \mathrm{a}-\mathrm{e}$

Storena tetrica Simon, 1908: 403 (description of + ).

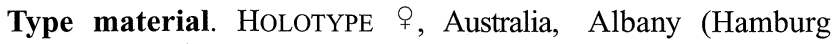
S.W. Austral. Exped. 1905, 13-22.VIII) (ZMB 24535) (examined).

Other material examined. WESTERN AUSTRALIA: $10,5 \circ 9+$, Augusta, 7 March 1927, W.S. Brooks (MCZ); $2 \uparrow q$, Pemberton, 17-20 March 1927, further as previous; 10 , $2 \% q$, Manjinup, January-February 1927, further as previous; $3 \% \uparrow, 25$ miles NW Walpole, 100 m, 26 September 1962, Ross \& Cavagnaro (CAS); 10*, Bedfordale, 2 April 1989, T. \& R. Bickley (WAM); 1 \% , Bedfordale, P. Hearne, 3 March 1988 (WAM);
Nornalup near Walpole National Park, 18 July 1982, A. Douglas (WAM); $2 \sigma^{\circ} \sigma^{\circ}$, Wilson Inlet, site $2,34^{\circ} 59^{\prime} \mathrm{S} 117^{\circ} 22^{\prime} \mathrm{E}$, 1 February 1986, G. Harold (WAM); $2 \sigma^{\circ} \sigma, 1 \%$, 1 juvenile, William Bay National Park, February-March 1988, R. MacMillan (WAM); 1 \%, Stirling Ranges, 15 May 1975, S. Slack-Smith (WAM); 1 , Peg Brookton Road, 30 m, April 1963, A. Jones (WAM); 1 \%, Augusta, c. $4 \mathrm{~km} \mathrm{E} \mathrm{Ellis}$ property, 25 October 1980, S. Slack-Smith (WAM); $10^{\circ}, 1$, Withcliffe, 11 April 1939, H. Glauert (WAM); 1 \%, William Bay National Park, 10 April 1982, McCrum (WAM); 10 , 2 우, $12 \mathrm{~km} \mathrm{~W}$ of Manjinup, 11 March 1971, H. Butler (WAM); 16, 1\%, Dombalup State Forest, Marri Road, $34^{\circ} 30^{\prime} \mathrm{S} 116^{\circ} 00^{\prime} \mathrm{E}, 15$ January 1979 , pitfall, M. Gray (AM KS15265); $10^{\circ}$, Burnside, Margaret River area, $33^{\circ} 56^{\prime} \mathrm{S}$ $115^{\circ} 01^{\prime} \mathrm{E}$, pitfall, 17 February 1979 , M. Gray (AM KS15132); 16, Boranup Drive Caves Road, $34^{\circ} 05^{\prime} \mathrm{S} 115^{\circ} 03^{\prime} \mathrm{E}, 17$ February 1979, pitfall, M. Gray (AM KS15158).

Diagnosis. The species is easily recognised by the large white dorsal patch in front of the spinnerets; the female is recognised by the simple epigyne with central oval depression, well delimited in front and on the sides and by the spermathecae without frontal extension, hardly touching in front. The male is recognised by the shape of the palpal tibia in which the dorsal concavity is delimited by two apophyses, it is further characterised by the posterior swollen extension of the tegulum and by the bifid frontal tegular membrane.

\section{Description}

Female. Total length $9.16 \mathrm{~mm}$; carapace $4.62 \mathrm{~mm}$ long, $2.96 \mathrm{~mm}$ wide.

Colour. Carapace, chelicerae and sternum reddish brown; legs orange; abdomen dark grey with rectangular or oval white dorsal patch in front of spinnerets (Fig. 4a). Venter sometimes with broad median white band. Carapace: smooth in cephalic area, slightly granulated in thoracic area. Fovea short, not deep.

Eyes in two strongly recurved rows; a, $0.17 ; \mathrm{b}, 0.16$; c, 0.12 ; d, 0.16; e, 0.08; f, 0.12; g, 0.14; h, 0.30. MOQ, $\mathrm{AW}=\mathrm{PW} ; \mathrm{AW}=0.90 \times \mathrm{L}$. Clypeus $0.44 \mathrm{~mm}$ high or 2.75 times width ALE; slightly retreating. Chilum double but separation of sclerites not complete; each half $0.70 \mathrm{~mm}$ wide and $0.30 \mathrm{~mm}$ high. There are two tiny sclerites underneath the larger ones. Chelicerae 1.78 $\mathrm{mm}$ long. Swollen, with large long condyle; almost bare except for distomesal group of setae in front of fangs. Sternum almost as wide $(1.66 \mathrm{~mm})$ as long $(1.87 \mathrm{~mm})$.

Legs: measurements and spination are given in Tables 2 and 3.

Palpus: claw with teeth; tarsus distally with long spines.

Epigyne (Fig. 4d,e) with central depression poorly delimited in the back well delimited in front, with two tiny openings in the middle. Entrance ducts complex; spermathecae near posterior margin, hardly touching in front; without frontal extension.

Male. Total length $9.25 \mathrm{~mm}$; carapace $4.83 \mathrm{~mm}$ long, $2.92 \mathrm{~mm}$ wide; ocular area $1.08 \mathrm{~mm}$ wide. 


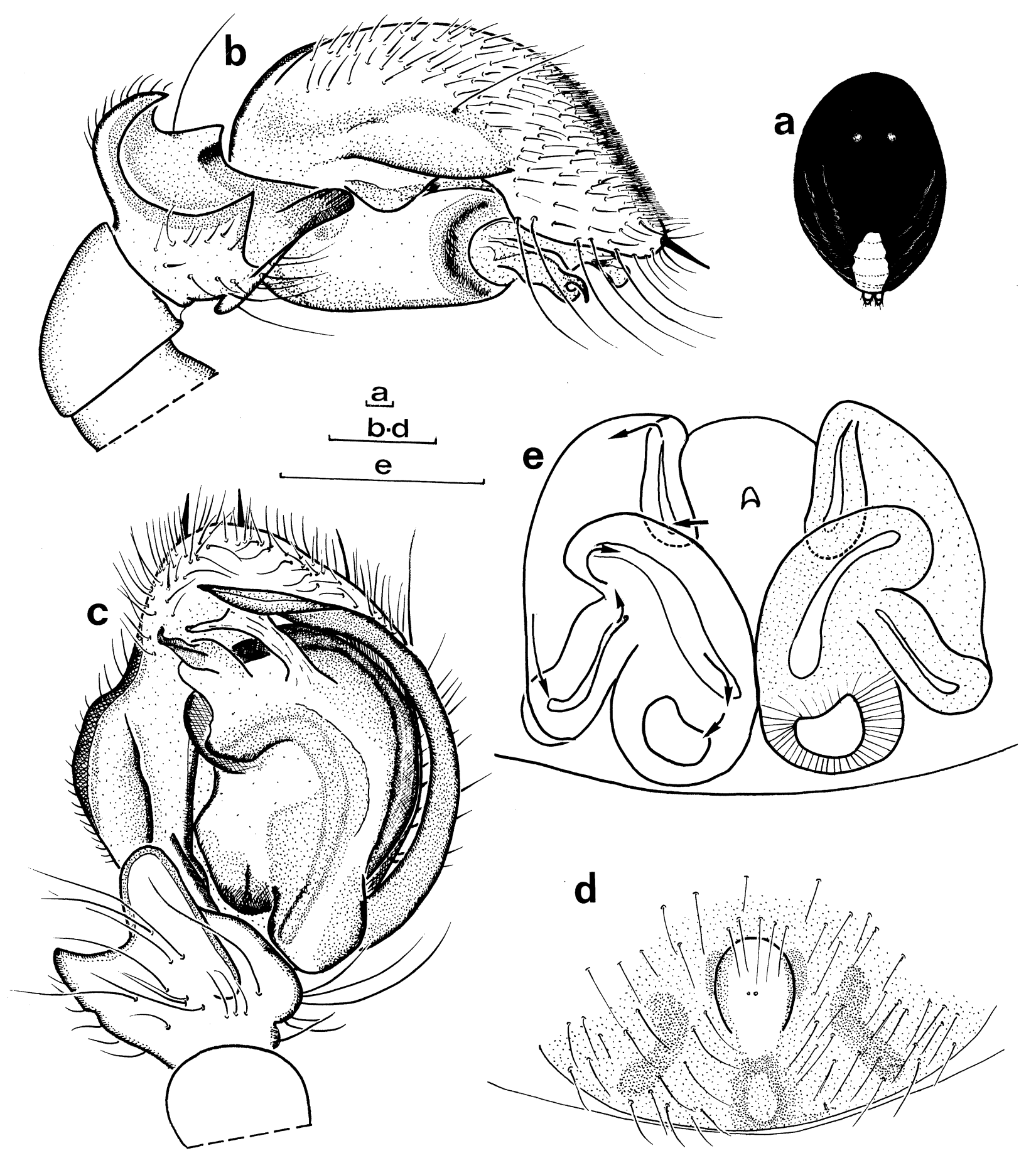

Fig. 4. Storosa tetrica (Simon) a, abdomen, ventral view, b, male palp, lateral view, c, male carapace, ventral view, d, epigyne, ventral view, e, epigyne, cleared, dorsal view. Arrows show course of entrance ducts. Scales $0.5 \mathrm{~mm}$.

Colour as female except for narrow brown scutum in frontal half of abdomen and sclerotised area in front of epigastric fold. Carapace slightly reticulate in cephalic area, more strongly so in thoracic area.

Eyes as in female. Sternal boss poorly developed.

Palp: Fig. 4b,c. Dorsal concavity of tibia posteriorly delimited by two apophyses, a dorsal one and a lateral one, and anteriorly produced into a short, rounded ventrolateral apophysis. Embolus massive, folded in distal part; tegular membrane slender; tegular apophysis with narrow distal part.

Distribution. South-western Western Australia. 


\section{Storosa obscura Jocqué}

Storosa obscura Jocqué, 1991: 91.

Material examined. QUEENSLAND: $2 \sigma^{\circ} \sigma$, SE Qld, Flinton Hill, via Ipswich, $120 \mathrm{~m}, 1975-1976$, G. \& S. Monteith (QM S12170); $4 \sigma^{\circ} \sigma^{\circ}$, as previous (QM S12147); 1 \% SE Qld, Upper Yarraman State Forest, via Maidenwell, $610 \mathrm{~m}$, 1974-1975, G. \& S. Monteith (QM S12172); 10, as previous (QM S12119); $1 \%$, Sarabah National Park, via Canungra, $120 \mathrm{~m}$, 1976-1977, G. \& S. Monteith (QM S12178); 1 6, SE Qld, Mount Nebo, 4 March 1988, P. Stevenson (QM S12244); 1 \% with cocoon, SE Qld, Mount Nebo, 29 October 1978, rainforest, in hole in ground, A. Rozefelds (QM S4417); 16, SE Qld, Mount Tenison Woods, via Mount Glorious, 762 m, 1975-1976, G. \& S. Monteith (QM S12177); 16, 1 , as previous (QM S12146); $1 \sigma^{\circ}, 1 \%$, as previous (QM S12216); $20^{\circ} \sigma^{\circ}$, Burnett Range, $15 \mathrm{~km}$ NE of Tansey, $400 \mathrm{~m}, 13$ December-26 March 1977, rainforest pitfall, G. \& S. Monteith (QM S12179); 10, as previous, 26 March-5 September 1977 (QM S12186); 10, as previous, 26 March-5 September 1977 (QM S12212); 16, SE Q1d, Kroombit Tops, 23-25 February 1982, pitfall in open forest with Casuarina, G.B.M., R.J.R., \& G. Thompson (QM S12160); 1 \%, Kroombit Tops, 45 km SSW Calliope, 9-19 December 1983, open forest, V. Davies \& J. Gallon (QM S4419); 16, Dulacca, 1 May 1928, J.C. Doherty (QM S4362); 16, mid-east Qld, Homevale, 1-7 April 1975, Riverine forest (QM S4375); 10, Upper Brookfield, CNVF with Araucaria, March-April 1981, pitfall, V. Davies \& R. Raven (QM S4330); $2 \sigma^{\circ} \sigma^{\circ}, 1$ \% , as previous, 3-18 March 1981 (QM S4312); 1 6 , as previous, 13 February-3 March 1981 (QM S4310); $5 \sigma^{\circ} \sigma^{\circ}$, as previous, 22 December 1980 (QM S4315); $1 \%$, as previous, 28 January 1981 (QM S4322); 10, Flinton Hill, via Ipswich $120 \mathrm{~m}$, rainforest pitfall, 1975-1976, G. \& S. Monteith (QM S12201); 2。 $\sigma^{\circ}, 1 \%$, SE Qld, Cooloola Freshwater Road, 122 m, April 1987, G. \& S. Monteith (QM S12202); $1 \sigma^{\circ}$, as previous (QM S3781); $1 \sigma^{\circ}$, as previous (QM S3778); $2 \sigma^{\circ} \sigma^{\circ}, 1+$, as previous, 1974-1975 (QM S12105); $4 \sigma^{\circ} \sigma^{\circ}$, as previous (QM S12107); 10, as previous (QM S12106); $3 \sigma^{\circ} \sigma$, $11^{\circ}$, SE Qld, Cooloola, Searys Scrub, 3-7 February 1976, R. Raven \& V. Davies (QM S4481); 30 ó, 1ㅇ, Cooloola, April 1978, G.B.M. (QM S12095); $70^{\circ} 0^{\circ}$, Cooloola, L. Poona, April 1978, G. Monteith (QM S12096); 1 ㅇ, Brisbane, Ferny Grove, March 1971, E. O'Brien (QM S4263); 10,1 , , Brisbane, Mount Coottha, 23 February 1980, R. Raven (QM S3751); $2 \sigma^{\circ} \sigma^{\circ}$, SE Qld, Top of Blackbutt Range, via Benarkin, 396 m, 1974-1975, G. \& S. Monteith (QM S12118); 16, as previous (QM S12117); 10 , SE Qld, base of Blackbutt Range, via Benarkin, 240 m, 29 March 1975, rainforest pitfall, G. \& S. Monteith (QM S12113); 1 б, 1 ${ }^{\circ}$, mid-east Qld, Blackdown Tableland, via Dingo, 1-6 February 1981, R. Raven (QM S3830); 16, Curtis Scrub, Canungra Creek, rainforest pitfall, 19761977, G. \& S. Monteith (QM S12192); 10, SE Qld, Braemar State Forest, 4-8 February 1980, R. Raven \& Q.M. (QM S4249); $3 \sigma^{\circ} \sigma$, SE Qld, Malaybrook, Bunya, 16 March 1976, pitfall, R. Raven \& V. Davies (QM 4482); 16,2 우, SE Q1d, Malaybrook, Bunya National Park, 17 March 1976, V. Davies \& R. Raven (QM S3841); 1 \%, SE Q1d, Stanthorpe, The Summit State School, 29 March 1984, W. McKenzie (QM S4443); 1 ㅇ, SE Qld, Little Yabba Creek, via Kenilworth, $152 \mathrm{~m}$, rainforest pitfall, 19741975, G. \& S. Monteith (QM S12099); NEW SOUTH WALES: $1 \sigma^{\circ}$, Broken Head, 30 m, 1975-1976, rainforest pitfall, G. \& S. Monteith (QM S12176); 1 $\sigma^{\circ}, 1$ 을 as previous (QM S12169); $2 \sigma \sigma$, as previous (QM S12215); $3 \sigma^{\circ}{ }^{\circ}$, as previous, 16 February-6 March 1976 (QM S12217); 1 ㅇ, northern NSW, Yabbra State Forest, 8 September 1974, R. Raven (QM S3782); $10^{\circ}$, Cherry Tree State Forest, via Mallanganee, rainforest pitfall, 19781979, G. \& S. Monteith (QM S3764); $20^{\circ} 0^{\circ}, 1$ ㅇ, Kiwarrak State Forest near Taree, $31^{\circ} 58^{\prime} \mathrm{S} 152^{\circ} 26^{\prime} \mathrm{E}, 10$ February 1980, pitfall, D. Milledge (AM KS6311); 10, Saint Ives, $33^{\circ} 44^{\prime} \mathrm{S} 151^{\circ} 10^{\prime} \mathrm{E}, 6$ March 1988, J. Muir (AM KS18721).

Distribution. Southern Queensland and New South Wales.

\section{Neostorena Rainbow \\ Neostorena torosa (Simon) n.comb.}

Fig. 5a

Storena torosa Simon, 1908: 404 (description of + ).--Rainbow, 1911: 152.--Jocqué, 1991: 91.

Remark. Jocqué (1991) supposed this species to belong in the genus Storosa. However, the abdominal colour pattern and the type of epigyne indicate that it should be placed in Neostorena. Males are needed to corroborate this placement.

Type material. HoLOTYPE $q$ : Western Australia, Northampton (ZMB 25436, examined).

Diagnosis. The female of this species is recognised by the shape of the epigyne with a central depression delimited by parallel lateral margins, a rounded anterior and a straight posterior margin.

\section{Description}

Female. Total length $13.05 \mathrm{~mm}$; carapace $6.44 \mathrm{~mm}$ long, $4.09 \mathrm{~mm}$ wide.

Colour. Carapace uniform reddish brown; chelicerae, sternum and legs orange brown; abdomen: sepia, dorsum in middle with a longitudinal series of nine pairs of pale spots; densely mottled with pale on remainder of dorsum and sides; venter pale with three interrupted longitudinal sepia stripes.

Eyes: a, 0.25; b, 0.20; c, 0.18; d, 0.25; e, 0.05; f, $0.28 ; \mathrm{g}, 0.13 ; \mathrm{h}, 0.54$. MOQ, $\mathrm{AW}=1.12 \times \mathrm{PW} ; \mathrm{AW}=$ $0.85 \times \mathrm{L}$.

Legs: measurements and spination are given in Tables 2 and 3.

Epigyne (Fig. 5a) central concavity delimited by parallel lateral margins, anterior margin rounded, posterior margin straight.

Distribution. Known only from the type locality in Western Australia. 

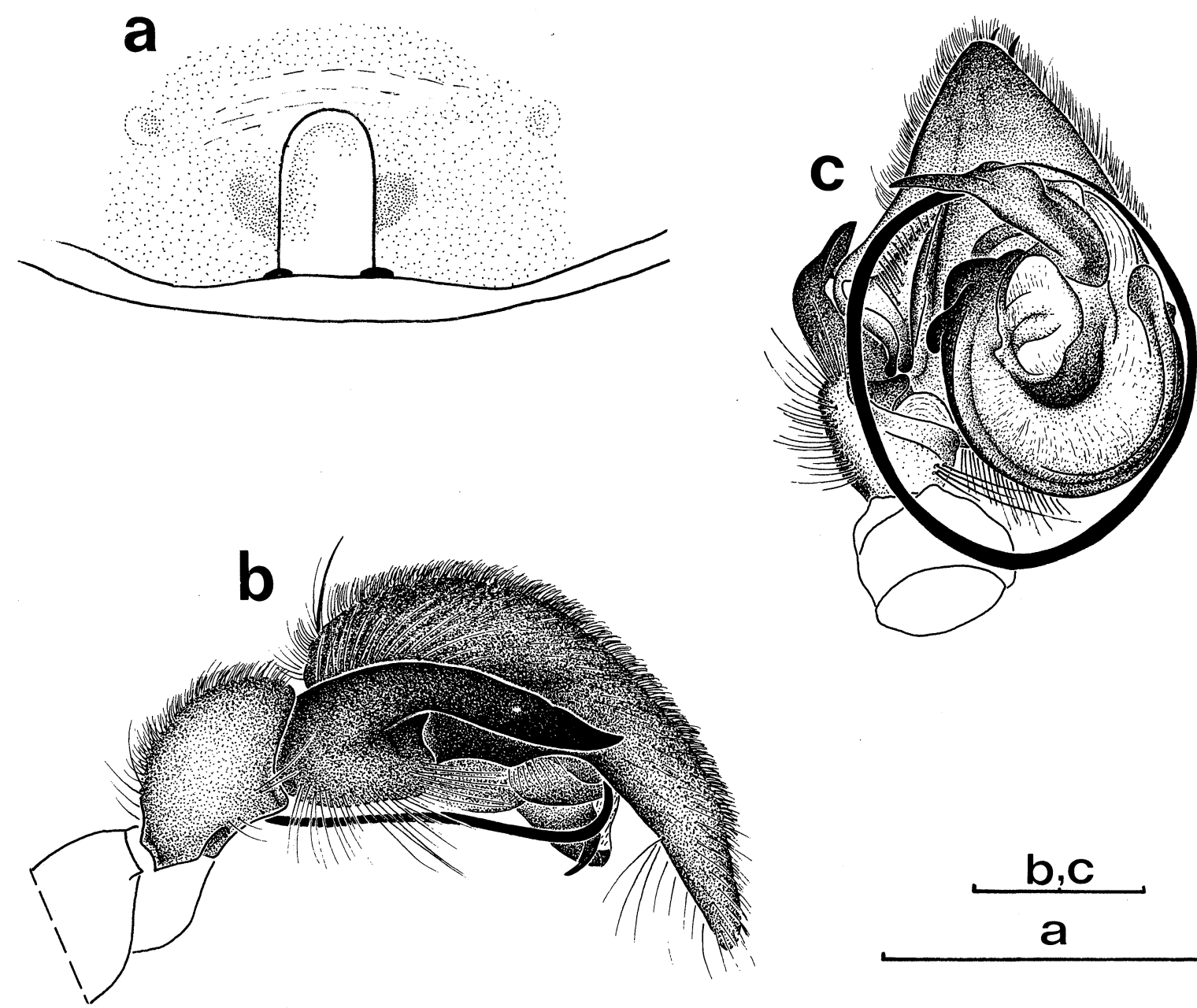

Fig. 5. Neostorena torosa (Simon) a, epigyne. Neostorena vituperata n.sp. b, male palp, lateral view; c, male palp, ventral view. Scales $1 \mathrm{~mm}$.

Neostorena vituperata n.sp.

Fig. 5b,c

Type material. HOLOTYPE $\sigma$ : north Queensland, Beagle North Camp, N of Aurukun, $13^{\circ} 05^{\prime} \mathrm{S} 141^{\circ} 38^{\prime} \mathrm{E}, 21$ March 1981, M. Robinson (AM KS8661). PARATYPES: 10, north Queensland, Cooktown, 15 ${ }^{\circ} 30^{\prime} \mathrm{S} 145^{\circ} 15^{\prime} \mathrm{E}$ (MNHN); $1 \sigma^{\prime}$, north Queensland, $15 \mathrm{~km} \mathrm{~N}$ Moorehead River, 3 September 1982, P. Davie (QM S3776).

Diagnosis. Males are recognised by the long pointed tibial apophysis in which the distal part is strongly bent inwards and is provided with a mesoventral denticle, the large cymbial fold with well-developed "exit" and the poorly developed tegular membrane for the largest part hidden by the tegular apophysis. The sternum is strongly rebordered and tarsi and metatarsi are provided with scopulae.
Etymology. A specimen of this species was initially chosen to serve as neotype for $N$. spirafera. For a few reasons (type locality, average size) it was not accepted as such whence its name vituperata (from Latin "vituperare", to reject).

\section{Description}

Male (holotype): total length $10.44 \mathrm{~mm}$; carapace 6.78 $\mathrm{mm}$ long, $4.96 \mathrm{~mm}$ wide.

Colour. Carapace uniform dark chestnut brown; chelicerae and legs dark brown; sternum dark brown, rebordered along lateral margins, borders black. Abdomen: dorsum sepia, with crescent-shaped white patch in front followed by a series of eight pairs of white spots and one larger spot in front of spinnerets; mottled with white between the spots. Sides mottled with white. Venter pale, with three longitudinal, interrupted dark sepia stripes. 

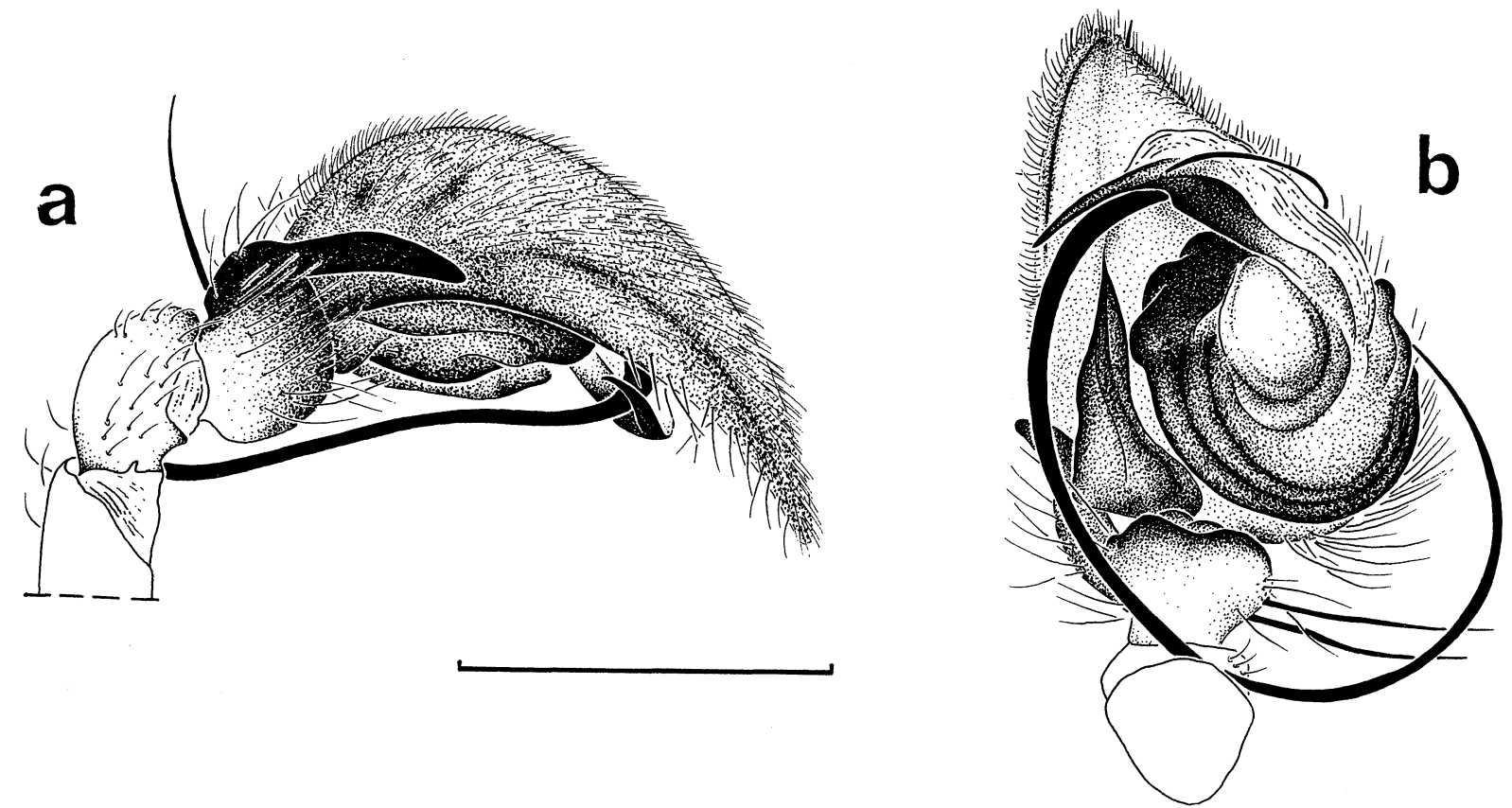

Fig. 6. Neostorena spirafera (Koch) a, male palp, lateral view, b, male palp, ventral view. Scales $1 \mathrm{~mm}$.

Eyes: a, 0.16; b, 0.14; c, 0.14; d, 0.14; e, 0.02; f, $0.12 ; \mathrm{g}, 0.04 ; \mathrm{h}, 0.16$. MOQ, $\mathrm{AW}=1.06 \times \mathrm{PW} ; \mathrm{AW}=$ $0.94 \times$ L. Clypeus $0.50 \mathrm{~mm}$ high or 3.6 times diameter of ALE.

Legs: measurements and spination are given in Tables 2 and 3. Several long hairs on tibiae, apparently replacing ventral spines. Scopulae well developed on tarsi and distal part of metatarsi.

Male palp (Fig. 5b,c): tibia with fairly long, pointed, lateral apophysis, bent inwards near middle, provided near bent with mesoventral denticle. Cymbium with large lateral fold, "exit" rather rounded, well developed; embolus originating on frontal part of tegulum, describing complete loop; tegular membrane almost completely hidden by tegular apophysis which gas thick base, bulging in the middle and with sharp, tapering distal part.

Distribution. North Queensland.

\section{Neostorena spirafera (Koch) n.comb.}

Fig. 6a,b

Habronestes spirafer Koch, 1872: 318 (description of б) not Habronestes spirafer.-Van Hasselt, 1887: 227.

Remark. The drawing of the male palp provided by Koch (1872, fig. 7d) is puzzling. Close examination reveals that it is a prolateral view; the large dark boss on the cymbium is in fact the large lateral fold and "exit" that can be seen from the prolateral side. It will therefore remain doubtful whether the specimens here described as $N$. spirafera are really conspecific with that species. However, the specimen described by Koch (1872) is quite small just as the neotype that is here selected. The type locality, "Port Mackay", is likely to be "Mackay" $\left(21^{\circ} 09^{\prime} \mathrm{S} 149^{\circ} 11^{\prime} \mathrm{E}\right)$ on the Central Queensland coast. The neotype is from an area about $400 \mathrm{~km}$ more to the north.

Type material. NEOTYPE $\sigma$ : Queensland: The Crater National Park, $17^{\circ} 25^{\prime} 30$ "S $145^{\circ} 15^{\prime} \mathrm{E}, 23$ July-26 November 1992, Q1d pitfall NQ27, R. Raven, E. Lawless \& M. Shaw (QM S24831).

Other material examined. QUEENSLAND: $1 \sigma, 3$ juveniles,

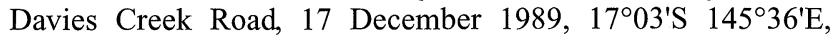
rainforest, $750 \mathrm{~m}$, berlese, G. Monteith \& G. Thompson (QMS 25699).

Diagnosis. Neostorena spirafera is a small species in which the male is characterised by the ventral abdominal area with short spines. The long lateral tibial apophysis is dorsoventrally flattened and provided with a short dorsal ridge near the tip.

\section{Description}

Male (holotype). Total length $6.56 \mathrm{~mm}$; carapace 3.28 $\mathrm{mm}$ long, $2.38 \mathrm{~mm}$ wide. 
Colour. Carapace and sternum uniform reddish brown; chelicerae and legs orange. Abdomen: dorsum dark grey with faint pattern in which two longitudinal rows of eight small white patches stand out; venter grey with faint pale with white between the spots. Sides mottled with white. Venter pale grey with faint darker pattern. Carapace and sternum reticulated. Abdomen on venter with broad longitudinal area covered with short hairs.

Eyes: a, $0.31 ; \mathrm{b}, 0.27$; c, 0.20 ; d, 0.26; e, 0.06; f, $0.18 ; \mathrm{g}, 0.16 ; \mathrm{h}, 0.40 . \mathrm{MOQ}, \mathrm{AW}=1.21 \times \mathrm{PW} ; \mathrm{AW}=$ $0.93 \times \mathrm{L}$. Clypeus $1.05 \mathrm{~mm}$ high or 3.9 times diameter of ALE.

Legs: measurements and spination are given in Tables 2 and 3. Several long hairs on tibiae, apparently replacing ventral spines. Scopulae well developed on tarsi and distal part of metatarsi.

Male palp (Fig. 6a,b): tibia with fairly long, pointed, lateral apophysis, bent inwards near middle, provided near bent with mesoventral denticle. cymbium with large lateral fold, "exit" rather rounded, well developed; embolus originating on frontal part of tegulum, describing complete loop; tegular membrane almost completely hidden by tegular apophysis which gas thick base, bulging in the middle and with sharp, tapering distal part.

Distribution. North-east Queensland.

\section{Neostorena minor Jocqué}

Neostorena minor Jocqué, 1991: 67.

Material examined. QUEENSLAND: 1 \% , SE Qld, The Head via Killarney, 760 m, 18 August-17 November 1974, G. \& S. Monteith (QM S12184); 1 \%, as previous, 17 November27 December 1974 (QM S12129); 1 \% , as previous, 31 March2 August 1975 (QM S12124); 1 ㅇ, Hoop Pine ?Mount Baldy, Atherton, 1969, C. Plowman (QM S4360); 10, SE Qld, Mount Goonaneman, via Childers, $670 \mathrm{~m}, 31$ March-4 September 1977, G. \& S. Monteith (QM S12180); $20 \sigma$, Border Fence, Lever's Flat, $670 \mathrm{~m}, 1975-1976$, G. \& S. Monteith (QM S12164); $20^{\circ} \sigma^{\circ}, 1$ \% , as previous (QM S12162, now in KBIN); 16 , SE Qld, Moreton Island, Blue Lagoon, 22 September 1982, pitfall, W. Houston (QM 3662); 10 , SE Qld, Mount Tenison Woods, via Mount Glorious, $762 \mathrm{~m}$, 1975-1976, G. \& S. Monteith (QM S12216); 1 \%, SE Qld, Brisbane, Gold Creek Reserve, 17 September 1980, R. Raven \& V. Davies (QM S4301); 10', SE Qld, O'Reillys, Lamington National Park, litter, 28 March 1976, R. Raven (QM S3725); 10, as previous, 8-18 July 1977 (QM S3842); 1 , NE Qld, Windin Falls, NW of Mount Bartle-Frere, $580 \mathrm{~m}$, 9 October 1980, berlese, G. Monteith (QM S3737); 1 ㅇ, SE Qld, Mount Chingee, $12 \mathrm{~km}$ SE Rathdowney, $72 \mathrm{O}$ m, 17 December 1982, rainforest litter, Monteith et al. (QM S4240); 10, SE Qld, Upper Tallebudgera Valley, 530 m, March-July 1985, D. Cook (QM S4262); 1, SE Qld, Upper Tallebudgera Valley, Below Springbrook, 300 m, 8 January-17 March 1985, Monteith et al. (QM S5254); 16, as previous (QM S4281); 1 + , SE Qld, Balvis Scrub, litter, 30 April 1980, G. Monteith (QM S3858); $1 \sigma$, Mistake Mountains, via Goomburra, $1040 \mathrm{~m}$, rainforest pitfall, 1976-1977, G. \& S. Monteith (QM S12185); 19, SE Qld, Bald Mountain, via Emu Vale, G. \& S. Monteith (QM
S12122); 10, as previous, 17 february-28 December 1974 (QM S12123); 10, Burpengary Creek, via Caboolture, rainforest pitfall, 1977-1978, G. \& S. Monteith (QM S12199); 10, Mount Mee Plateau Site, $550 \mathrm{~m}$, rainforest pitfall, 1977-1978, G. \& S. Monteith (QM S12196); 10, Upper Brookfield, CNVF with Araucaria, 14-28 November 1980, pitfall, V. Davies \& R. Raven (QM S4314); 1o', as previous, 15 October 1980 (QM S4313); $10^{\circ}$, as previous, 28 November-11 December 1980 (QM S4328); 16 , as previous, 30 October 1980 (QM S4327); 3 우, SE Qld, Mount Hobwe, Lamington National Park, 3-8 April 1976, pitfall, R. Raven \& V. Davies (QM S4479); $20^{\circ}$ o', Binna Burra, Lamington National Park, 30 March 1976, V. Davies \& R. Raven (QM S3852); 10, SE Q1d, Top of Blackbutt Range, via Benarkin, 396 m, 1974-1975, G. \& S. Monteith (QM S12116); 1 $\sigma$, base of Blackbutt Range, via Benarkin, $244 \mathrm{~m}$, rainforest pitfall, 1974-1975, G. \& S. Monteith (QM S12115); 20 o', SE Q1d, Cunningham's Gap, $762 \mathrm{~m}$, rainforest pitfall, 1974-1975, G. \& S. Monteith (QM S12136); $3 \sigma \sigma^{\prime}$, Philp Farm, Lever's Flat, via Rathdowney, $640 \mathrm{~m}$, rainforest pitfall, 1975-1976, G. \& S. Monteith (QM S12218); 10, SE Qld, Casey Creek, via Imbil, 90 $\mathrm{m}$, rainforest pitfall, 1974-1975, G. \& S. Monteith (QM S12101); 1o, SE Qld, Mary Cairncross Park, $488 \mathrm{~m}$, rainforest pitfall, 1974-1975, G. \& S. Monteith (QM S12097); 19, NEQ, Mount Edith, Lamb Range, $1050 \mathrm{~m}$, 12 October 1982, rainforest litter, berlese, Monteith et al. (QM S3801); 1 \% , Lake Broadwater, via Dalby, pitfalls site 3, 17 May-24 November 1985, QM \& M. Bennie (QM S15730). NEW SoUTH WALES: $20^{\circ} \sigma^{\circ}$, Toonumbar State Forest, via Grevillea, $610 \mathrm{~m}$, rainforest pitfall, 17 November27 December 1974, G. \& S. Monteith (QM S12132); 10, Toonumbar State Forest, via Grevillea, $610 \mathrm{~m}$, rainforest pitfall, 1974-1975, G. \& S. Monteith (QM S12194); 16, as previous (QM S12130); $2 \sigma^{\circ} \sigma^{\circ}$, New Brighton Beach, via Brunswick Heads, $10 \mathrm{~m}$, rainforest pitfall, 1974-1975, G. \& S. Monteith (QM S12214); 10, as previous (QM S12140); 1 ㅇ, northern NSW, Tooloom Scrub, rain forest litter, 28 April 1983, G. Thompson (QM 4273); 16, $1 \%$, NE NSW, Nothofagus Mountain, via Woodenbong, $1100 \mathrm{~m}$, 17 June 1982, berlese, Nothofagus litter, G. Monteith \& G. Thompson (QM S4252).

Distribution. Queensland, New South Wales.

\section{Mallinella Strand}

\section{Mallinella zebra (Thorell) n.comb.}

Fig. $7 \mathrm{a}-\mathrm{d}$

Storena zebra Thorell, 1881: 184 (description of $\sigma$ ).-Strand, 1911: 132.-Hogg, 1915: 439.

Type material. Holotype $\sigma$ : Aru Islands, Vakan, O. Beccari (MCSNG) (examined).

Other material examined. NEW GUINEA: $7 \sigma^{\circ} \circ$, Mundiptera 1962, B. Monulf (RMNH 8145). AUSTRALIA, QUEENSLAND: 16 , Iron Range Cape York, 9 July 1971, G. Monteith (QM S3713); $20^{\circ} \sigma^{\circ}, 2+9$, Lowland and Highland, Lamond Hill from RNNEQ, 25 June-6 July 1976, pitfall, R. Raven \& V. Davies (QM S4474); 10, 1\%, NNEQ, East Claudie Scrub, Iron Rabge, 25 June 1976 (QM S4473). 

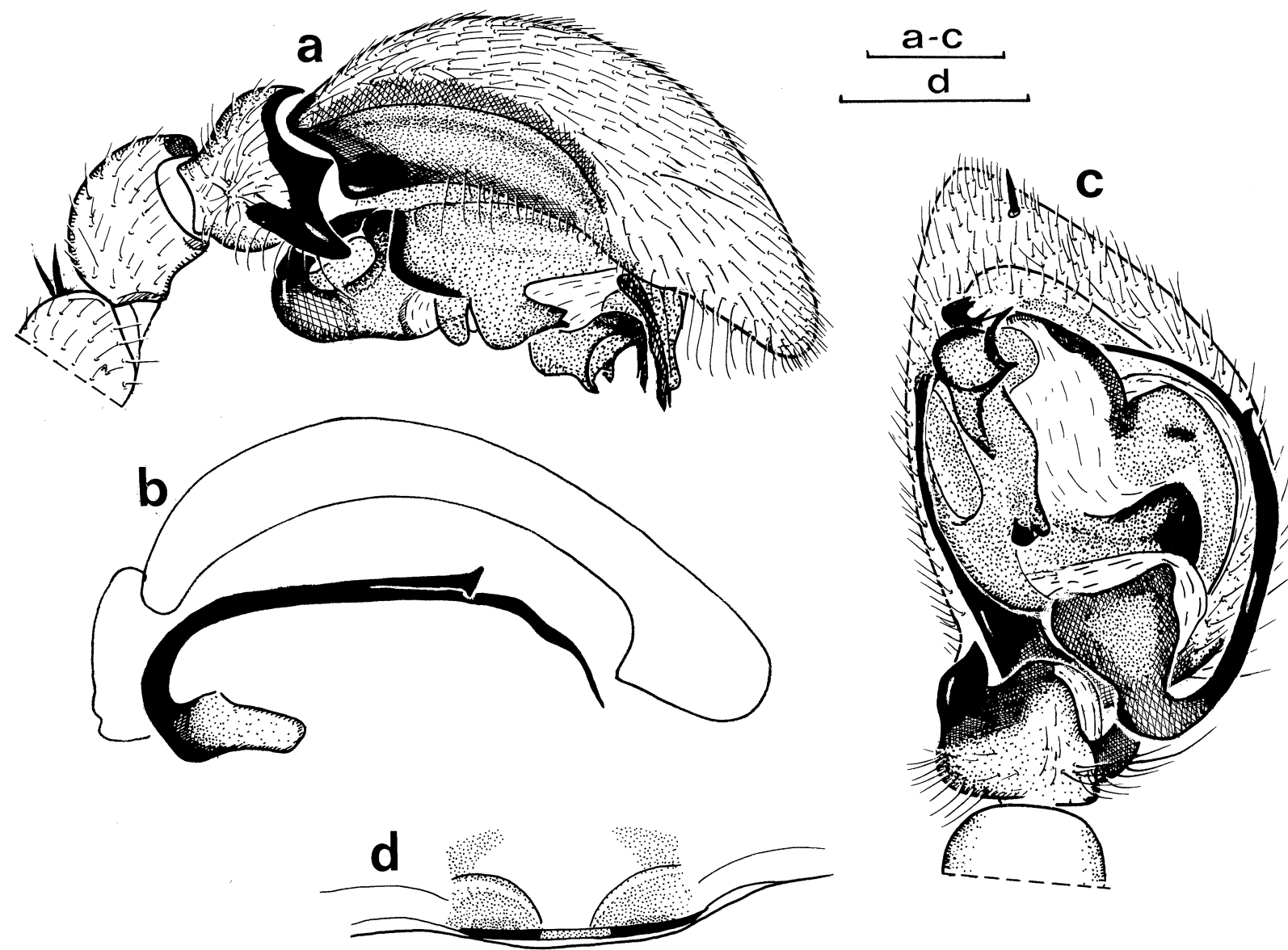

Fig. 7. Mallinella zebra (Thorell): a, male palp, lateral view, b, male palp, mesal view, showing split embolus; c, male palp, ventral view, d, epigyne. Scales $0.5 \mathrm{~mm}$.

Diagnosis. The male is easily recognised by the characteristics of its palp i.e. the embolus with partly split section ending in a transverse tooth and the details of tegular apophysis and conductor.

\section{Description}

Male. Total length $6.29 \mathrm{~mm}$; carapace $3.33 \mathrm{~mm}$ long, $2.29 \mathrm{~mm}$ wide.

Colour. Carapace and chelicerae dark brown; sternum orange; legs yellowish orange. Abdomen sepia with two rows of three pale spots on posterior part of dorsum and two oblique pale stripes on sides; venter pale.

Eyes: a, 0.25 ; b, 0.13 ; c, 0.15 ; d, 0.16 ; e, 0.10 ; f, $0.07 ; \mathrm{g}, 0.31 ; \mathrm{h}, 0.31$ MOQ, $\mathrm{AW}=1.30 \times \mathrm{PW} ; \mathrm{AW}=$ $1.00 \times \mathrm{L}$. Clypeus straight; $0.71 \mathrm{~mm}$ high or 5.46 times width of ALE.

Legs: measurements and spination are given in Tables 2 and 3.

Male palp (Fig. 7a-c): tibia with short, strong, downcurved prolateral apophysis; cymbial fold reaching to $2 / 3$ length of cymbium; embolus originating on posterior part of tegulum, split over $1 / 4$ of its length
(Fig. 7b), the short part with a transversal tooth at its extremity; tegular apophysis with one short proximal tooth, one double tooth in middle and fine prong at tip; conductor with two narrow prongs distally.

Female (QM S4474). Total length $6.52 \mathrm{~mm}$; carapace $3.02 \mathrm{~mm}$ long, $2.13 \mathrm{~mm}$ wide.

Colour. Carapace and chelicerae medium brown; sternum orange; legs yellowish orange with darker stripes on femora. Abdomen grey with three pale spots in front of spinnerets on dorsum, sides uniform greyish sepia; venter grey mottled with pale in front.

Eyes: a, $0.20 ; \mathrm{b}, 0.18$; c, 0.16 ; d, 0.20 ; e, 0.05 ; f, $0.10 ; \mathrm{g}, 0.16 ; \mathrm{h}, 0.25$. MOQ, $\mathrm{AW}=1.05 \times \mathrm{PW}$; AW $=$ $0.81 \times$ L. Clypeus straight: $0.73 \mathrm{~mm}$ high or 4.05 times width of ALE.

Legs: measurements and spination are given in Tables 2 and 3.

Epigyne (Fig. 7d) very simple, just a transversal slit with spermathecae shining through.

Distribution. New Guinea and north Queensland. 


\section{Nostera Jocqué}

Remarks. The generic definition of Nostera Jocque is here widened to enable the inclusion of species with a slender embolus. According to the original diagnosis by Jocqué (1991), Nostera males have a short, straight embolus originating on the anterior part of the tegulum. It is clear from the studies of Jocque \& Baehr (1992) and Baehr \& Jocqué (1994) that within a genus, namely Storena, the palpal structure can change extensively although the basic conformation remains the same. In that genus the most plesiomorphic species have a short straight, self-supporting embolus, inserted on the distal end of the tegulum. In the course of the evolution the embolus becomes long and slender which results in insertion further back on the tegulum and the development of one or more tegular apophyses which function as conductors. The former stage is similar to what is found in Nostera lynx Jocque whereas the situation in $N$. nadgee $\mathrm{n}$.sp. can be compared with that in the more apomorphic species of Storena. However, whereas Storena is easily defined by its somatic characters, this is not the case with Nostera which may be regarded as a plesiomorphic genus, difficult to define. It may prove to be polyphyletic but it will need a thorough revision to conclude that the species placed in it do indeed belong to the same genus.

Diagnosis. Representatives of this genus have three rows of trichobothria on the tibiae; males are recognised by the simple male palpal tibia with distal retrolateral apophysis, the cymbium with proximal lateral flange and by the basic palpal conformation with a laterally inserted embolus and a membranous distal tegular apophysis, sometimes with an additional sclerified apophysis when the embolus is long and slender. Females have an epigynum with central membranous area; the entrance ducts begin at its anterior edge and lead to a pair of large spermathecae on the posterior rim of the epigyne.

\section{Nostera leucosema (Rainbow) n.comb.}

\section{Fig. 8a}

Storena leucosema Rainbow, 1920: 237 (description of + ).

Remarks. The placement of this species in Nostera is tentative; in the absence of males there is no real clue as to what genus it belongs. However, it cannot be included any longer in Storena as that genus is now well defined (Jocqué \& Baehr, 1992). The somatic characters match more or less those of Nostera but the lack of teeth on the chelicerae prompts caution. There is also some resemblance to Neostorena, but in that genus the chilum is always clearly double.

Type material. LECTOTYPE + (by present designation): Australia, NSW, Lord Howe Island, top of Mount Gower K 39461 (AM KS6685) (examined). PARALECTOTYPES: 2 juveniles together with lectotype.
Other material examined. LORD HOWE ISLAND: 19 , North Hill, 130 m, 17-28 May 1980, S. \& J. Peck, dung cup traps, lowland forest (AMNH); 1 \% 2 juveniles, as above, Stephens Reserve 25 May 1980, litter under bark (AMNH); 19, $31^{\circ} 33^{\prime} \mathrm{S} 159^{\circ} 05^{\prime} \mathrm{E}$, February 1971 (SAM, AM KS15672).

Diagnosis. The females of this species differ from other Nostera by the lack of teeth on the promargin of the chelicerae.

\section{Description}

Female. Total length $6.50 \mathrm{~mm}$; carapace $3.58 \mathrm{~mm}$ long, $2.37 \mathrm{~mm}$ wide.

Colour. Carapace reddish brown, somewhat paler in front of fovea; chelicerae reddish brown, sternum orange; legs: femora, patellae, tibiae and base of metatarsi yellow, remainder orange. Abdomen pale sepia; dorsum with white patches in posterior half; a pair of crescentshaped ones followed by two smaller oval ones and a single larger patch in front of the spinnerets; in some specimens there are two large extra patches in front.

Eyes: a, $1.00(0.11)$; b, 1.18; c, 1.22; d, 1.18; e, 0.45; f, $0.82 ; \mathrm{g}, 0.72 ; \mathrm{h}, 1.72 . \mathrm{MOQ}, \mathrm{AW}=0.77 \times \mathrm{PW} ; \mathrm{AW}$ $=0.67 \times \mathrm{L}$. Clypeus $0.42 \mathrm{~mm}$ high or c. 3 times the diameter of an ALE, convex with few small hairs. Chilum double, two narrow sclerites connected dorsally by narrow strip. Chelicerae with anteromesal scopula, without teeth.

Legs: measurements and spination are given in Tables 2 and 3. Metatarsi with distal hair tufts.

Abdomen oval; spinnerets 6; no row of spines in front of spinnerets. Tracheal spiracle crescent-shaped.

Epigyne (Fig. 8a) a poorly sclerotised flat area with only posterior rim darkened; coiled spermathecae near posterior margin shining through.

Male. Unknown.

Distribution. Lord Howe Island.

\section{Nostera nadgee n.sp.}

Fig. $8 b-d$

Remarks. Although the aim of the present paper is not to describe new species, I thought it necessary to describe this taxon as it occurs together with Nostera leucosema on Lord Howe Island. The latter species is only known from females and has a similar size and colour pattern. I therefore initially thought that the males of $N$. nadgee were those of $N$. leucosema until I matched the correct females.

Type material. HolOTYPE $\sigma$ : Australia, NSW, Nadgee Nature Reserve $37^{\circ} 27^{\prime} \mathrm{S} 149^{\circ} 56^{\prime} \mathrm{E}, 24$ May 1978, pitfall, G. Gowing (AM ex KS 1609). PARATYPES: $16 \sigma^{\circ} \sigma$, together with holotype (AM KS37842). 

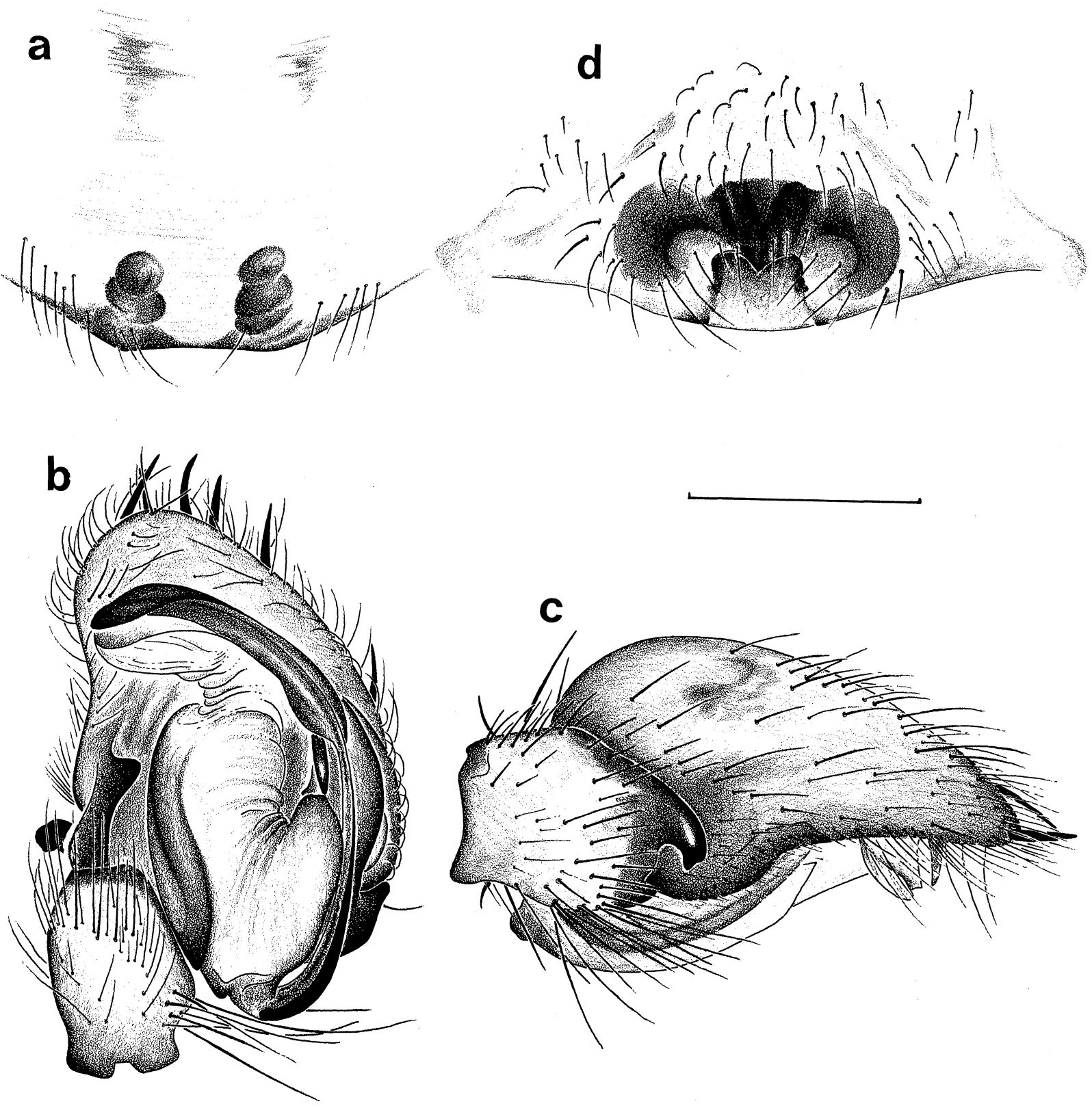

Fig. 8. Nostera leucosema (Rainbow): a, epigyne, ventral view. Nostera nadgee n.sp. b, male palp, lateral view, c, male palp, lateral view, d, epigyne, ventral view. Arrows show course of entrance ducts. Scale $0.5 \mathrm{~mm}$.

Other material examined. LORD HOWE ISLAND: 19 , Transit Hill, c. 110 m, 17 May 1980 , berlese rotting wood, tall forest, S. \& J. Peck (AMNH); 1 , North Hill, c. $260 \mathrm{~m}$, berlese rotting wood, low forest, 17 May 1980, S. \& J. Peck (AMNH); 10 , $2+\%$, many juveniles, Roach Island, 27 May 1980, berlese of litter in seabird burrows and rock crevices, S. \& J. Peck (AMNH); $1 \sigma^{\prime}, 31^{\circ} 33^{\prime} \mathrm{S} 159^{\circ} 05^{\prime} \mathrm{E}$, February 1971, in moist log, M. Gray (AM KS15565). QUEENSLAND: $3 \sigma^{\circ} \sigma^{\circ}$, NE

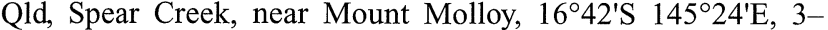
10 November 1975 , pitfall in notophyll vine forest, R. Raven \& V. Davies (QM S4461). NEW SouTH Wales: 10, Cuningar via Harden, $34^{\circ} 34^{\prime} \mathrm{S} 148^{\circ} 25^{\prime} \mathrm{E}, 20$ June 1979, N. Pigram (AM KS3086); 10", Neutral Bay, 9 June 1981, L. Hopwood (AM

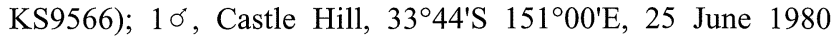
(AM KS5339).

Diagnosis. The females of this species differ from other Nostera by the epigyne with central depression of which the anterior margin has a protruding rounded lip; the male is recognised by the short tibial apophysis, strongly curved down and with a truncated, slightly indented tip.

Etymology. Nadgee is a noun in apposition taken from the type locality. 


\section{Description}

Male. Total length $5.62 \mathrm{~mm}$; carapace $3.06 \mathrm{~mm}$ long, $2.13 \mathrm{~mm}$ wide.

Colour. Carapace uniform medium brown, with very faint radiating striae. Somewhat paler in front of fovea; chelicerae reddish brown, sternum orange; legs yellowish orange, femora markedly darker. Abdomen sepia; dorsum with 1 pair of white spots in front, separated by narrow pale brown scutum; followed by seven pale chevrons, the frontal one sometimes divided into two spots; sides sepia mottled with white and with two oblique stripes in posterior half; venter pale with two ill-defined longitudinal pale sepia stripes.

Eyes: a, 0.12; b, 0.15; c, 0.11; d, 0.13; e, 0.03; f, $0.05 ; \mathrm{g}, 0.05 ; \mathrm{h}, 0.13$. MOQ, AW $=\mathrm{PW} ; \mathrm{AW}=0.73 \times \mathrm{L}$. Clypeus $0.20 \mathrm{~mm}$ high or 1.33 times the diameter of an ALE, almost straight, with few small hairs. Chilum single. Chelicerae with anteromesal scopula, with two teeth on anterior margin.

Legs: measurements and spination are given in Tables 2 and 3.

Male palp (Fig. 8b,c): palpal tibia with short downcurved apophysis, tip truncated and finely indented. Tegulum with well-developed terminal membrane and large conductor-like sclerite originating mesodorsally on posterior part of tegulum; embolus thin and relatively short, originating far back on tegulum.

Female (from Transit Hill). Total length $7.24 \mathrm{~mm}$; carapace $2.94 \mathrm{~mm}$ long, $1.87 \mathrm{~mm}$ wide.

Colour. As in male; femora not darker than remainder of legs but these darker towards tarsus; oblique stripes on sides of abdomen larger and sometimes three in stead of two.

Eyes: a, $0.11 ; \mathrm{b}, 0.14 ; \mathrm{c}, 0.10 ; \mathrm{d}, 0.13$; e, $0.02 ; \mathrm{f}$, $0.03 ; \mathrm{g}, 0.02 ; \mathrm{h}, 0.11 . \mathrm{MOQ}, \mathrm{AW}=1.09 \times \mathrm{PW} ; \mathrm{AW}=$ $0.73 \times \mathrm{L}$. Clypeus $0.19 \mathrm{~mm}$ high or 1.36 times the diameter of an ALE, straight, with few small hairs. Chilum single. Chelicerae with two teeth on anterior margin.

Legs: measurements and spination are given in Tables 2 and 3.

Epigyne (Fig. 8d) with well delimited central depression; its anterior margin with protruding and rounded lip.

Variation. There is a large size variation in this species. By far the largest specimens are those from Roach Island (male, total length $6.73 \mathrm{~mm}$, carapace width 2.43 $\mathrm{mm}$, length $3.41 \mathrm{~mm}$ ); the males from New South Wales are smaller (total length $4.77-6.39 \mathrm{~mm}$, carapace width $1.79-2.30 \mathrm{~mm}$, length $2.60-3.41 \mathrm{~mm}$ ) whereas those from Queensland are very small (total length 3.83-4.34 $\mathrm{mm}$; carapace width $1.32-1.49 \mathrm{~mm}$, length $2.00-2.17$ $\mathrm{mm})$.

Distribution. Lord Howe Island, New South Wales and Queensland.
Nostera lynx Jocqué

Nostera lynx Jocqué, 1991: 72.

Material examined. QUEENSLAND: 1 $\sigma$, Sarabah National Park, via Canungra, $120 \mathrm{~m}, 1976-1977$, G. \& S. Monteith (QM S12173); 10', Plateau south of The Head, via Killarney, pitfall 21, 17 February-27 December 1974, G. \& S. Monteith (QM S12167); 16, as previous, 17 November-27 December 1974 (QM S12129); 2 \% , The Head, via Killarney, $760 \mathrm{~m}$, pitfall, 1974, G. \& S. Monteith (QM S12128); 1 , SE Qld, Teviot Falls, via Boonah, $820 \mathrm{~m}, 1976-1977$, G. \& S. Monteith (QM S12211); 1 9 , SE Qld, Lamington Plateau, 21 April 1975, R. Raven (QM 4437); 10 , SE Qld, Plateau south of The Head, via Killarney, 18 August-17 November 1974, pitfall, G. \& S. Monteith (QM S12125); 1 \% , SE Qld, Binna Burra, 25 June 1966, leaf litter, C. Plowman (QM S4395); 10 , Binna Burra, Lamington National Park, 30 March 1976, V. Davies \& R. Raven (QM S3852); $29 \%$, as previous, 27 March 1976 (QM S4477); 1 9 , SE Qld, Rozen's Lookout, Beechmont, $448 \mathrm{~m}$, rainforest pitfall, 1974-1975 G. \& S. Monteith (QM S12190); 16 , SE Qld, Bald Mountain, via Emu Vale, G. \& S. Monteith (QM S12120); 20 $\sigma^{\circ}$, as previous, 17 November-28 December 1974 (QM S12123); 10, 1 \% , as previous (QM S12121); 10, O'Reillys, Lamington National Park, 17 March 1981, J. Stanisic \& D. Potter (QM S4409); 10 , O'Reillys, Lamington National Park, 15 November 1977, by night, YED, ED \& R. Raven (QM S4475); $10^{\circ}$, Cainbable, via Lamington National Park, 762 m, rainforest pitfall, 19751976, G. \& S. Monteith (QM S12204); 10, Tamborine, Palmgrove, 26 October-14 December 1974, pitfall, G. \& S. Monteith (QM S12138). NeW South WALES: 2 $q$, Mount Glennie, $16 \mathrm{~km}$ E Woodenbong, 910 m, 25 November 1982, rainforest litter, berlese, Monteith et al. (QM S4237); 16 , Toonumbar State Forest, via Grevillea, $610 \mathrm{~m}$, rainforest pitfall, 1974-1975, G. \& S. Monteith (QM S12194).

Distribution. Queensland and New South Wales.

Hetaerica Rainbow

Hetaerica variegata (Pickard-Cambridge)

Storena variegata Pickard-Cambridge, 1869: 53 (description of juvenile).

Habronestes variegatus.-Koch, 1872: 302 (description of juvenile).

Remarks. Although both Pickard-Cambridge (1869) and Koch (1872) stated that they had described adult females, the holotype (UMO, examined) is clearly a juvenile. Hickman (1950) designated a "cotype" (NVM, examined) for this species which is a female. As there is no evidence that the juvenile holotype and the specimen described by Hickman are conspecific, we regard the designation of a cotype, as well as his identification, as invalid. If one also considers that it is impossible to identify the genus as the type species Hetaerica aresca Rainbow is also known only from juveniles (see Jocqué, 1991: 60) it is decided here to invalidate both species and the genus Hetaerica. 
ACKNOWLEDGMENTS. I am much indebted to the curators at the institutions listed earlier. I thank A. Reygel for the preparation of some of the drawings. I also thank two anonymous reviewers who insisted upon some more clearcut taxonomical decisions I would not have made alone.

\section{References}

Baehr, B. \& R. Jocqué, 1994. Phylogeny and zoogeography of the Australian spider species Storena. Spixiana 17: 112.

Butler, A.G., 1876. On a small collection of Arachnida from Queensland with descriptions of three apparently new species. Systematic Entomology 1: 349-354.

Davies, V.T., 1985. Araneomorphae (in part). In Zoological Catalogue of Australia, vol. 3: Arachnida, pp. 49-125. Canberra: Australian Government Publications Service.

Dunn, R.A., 1951. Spiders of the Russell Grimwade expedition. Memoirs of the national Museum of Melbourne 17: 918.

Hasselt, A.W.M. Van, 1887. Araneae exoticae quas collegit, pro Museo Lugdunensi, J. Neervoort van de Poll insulis Curaçao, Bonaire et Aruba. Tijdschrift voor Entomologie 30: $227-244$.

Hickman, V.V., 1944. The Simpson Desert Expedition, 1939. Scientific report 1. Biology - Scorpions and spiders. Transactions of the Royal Society of South Australia. 68: $18-48$.

Hickman, V.V., 1950. Araneae from Reevesby Island, South Australia. Proceedings of the Royal Society of Victoria (new series) 60: 1-16.

Hogg, H.R., 1900. A contribution to our knowledge of the spiders of Victoria: including some new species and genera. Proceedings of the Royal Society of Victoria 13: 68-123, pl XIII-XVII.

Hogg, H.R., 1915. Report on the spiders collected by the British ornithologist's Union expedition and the Wollaston expedition in Dutch New Guinea. Transactions of the Zoological Society of London 1915: 501-582.

Jocqué, R., 1991. A generic revision of the spider family Zodariidae. Bulletin of the American Museum of Natural History 201: 1-160.

Jocqué, R., 1995. Notes on Australian Zodariidae (Araneae), I. New taxa and key to the genera. Records of the Australian Museum 47(2): 117-140 (this issue).

Jocqué, R. \& B. Baehr, 1992. A revision of the Australian spider genus Storena (Araneae, Zodariidae). Invertebrate Taxonomy 6: 953-1004.

Koch, L., 1872. Die Arachniden Australiens. Nürnberg, 105368.

Kritscher, E., 1956. Bisher unbekannt gebliebene AraneenMänchen und -Weibchen des Wiener Naturhistorischen Museum. (I. Teil). Annalen des naturhistorischen Museums zu Wien. 61: 254-272.

Pickard-Cambridge, O., 1869. Descriptions and sketches of some new species of Araneidea, with characters of a new genus. Annals and Magazine of Natural History (4) III: 52-74.

Rainbow, W.J., 1911. A census of Australian Araneidae. Records of the Australian Museum 9: 107-319.

Rainbow, W.J., 1912. Araneidae from the Blackall Ranges. Memoirs of the Queensland Museum 1: 190-202.
Rainbow, W.J., 1920. Arachnida from Lord Howe and Norfolk Islands. Records of the South Australian Museum 1: 229272.

Simon, E., 1893. Histoire naturelle des Araignées. Paris 1(2) 1893: $257-488$.

Simon, E., 1908. Araneae. 1re partie. in "Die Fauna Südwest Australiens" (eds W. Michaelsen \& R. Hartmeyer) 1 (12): 359-446. Fisher Verlag, Jena.

Strand, E., 1911. Araneae von den Aru- und Kei-Inseln. Abhandlungen der senckenbergischen naturforschenden Gesellschaft. 34: 129-199.

Thorell, T., 1881. Studi sui ragni Malesi e Papuani dell'AustroMalesia e del Capo York, conservati nel Museo civico di Storia naturale di Genova Annali del Museo civico di Storia naturale di Genova 17: VII-XVII, 1-720.

Accepted 23 July, 1994 
Table 1. List of Australian Zodariidae described before Jocqué (1991). Annotation: 1, paratype status; 2, synonym of Storena cyanea.

\begin{tabular}{|c|c|c|c|c|c|c|}
\hline species & author & year & $\begin{array}{l}\text { initial } \\
\text { genus }\end{array}$ & $\begin{array}{l}\text { present } \\
\text { genus }\end{array}$ & $\begin{array}{l}\text { type } \\
\text { depository }\end{array}$ & $\begin{array}{l}\text { type } \\
\text { status }\end{array}$ \\
\hline annulipes & Koch & 1867 & Enyo & Habronestes & $\mathrm{ZMH}$ & juv \\
\hline aresca & Rainbow & 1916 & Hetaerica & Hetaerica & $\mathrm{AM}$ & juv \\
\hline australiensis & Pickard-Cambridge & 1869 & Storena & Habronestes & UMO & + \\
\hline braccata & Koch & 1867 & Enyo & ? & $\mathrm{ZMH}$ & juv \\
\hline bradleyi & Pickard-Cambridge & 1869 & Storena & Habronestes & UMO & 0 \\
\hline colossea & Rainbow & 1920 & Storena & Storena & SAMA & $?$ \\
\hline cyanea & Walckenaer & 1805 & Storena & Storena & $\mathrm{AM}$ & $\sigma$ \\
\hline eximia & Simon & 1908 & Storena & Storena & $\mathrm{ZMB}$ & juv $^{1}$ \\
\hline flavipedes & Urquhart & 1893 & Habronestes & ? & lost & \\
\hline formosa & Thorell & 1870 & Storena & Storena & NRS & q \\
\hline graeffei & Koch & 1867 & Storena & $?$ & $\mathrm{ZMH}$ & juv \\
\hline grimwadei & Dunn & 1951 & Storena & Habronestes & NVM & Q \\
\hline inornata & Rainbow & 1916 & Storena & ? & lost & \\
\hline leucosema & Rainbow & 1920 & Storena & Nostera & $\mathrm{AM}$ & $\sigma$ \\
\hline macedonensis & Hogg & 1900 & Storena & Habronestes & $\mathrm{BMNH}$ & $\sigma$ \\
\hline maculata & Pickard-Cambridge & 1869 & Storena & ? & UMO & juv \\
\hline ornatus & Bradley & 1878 & Habronestes & ? & lost & \\
\hline picta & Koch & 1865 & Enyo & $?$ & lost & \\
\hline procera & Thorell & 1890 & Storena & Storena & NRS & $q^{2}$ \\
\hline rastellata & Strand & 1913 & Storena & ? & SMF & juv \\
\hline rufescens & Thorell & 1881 & Storena & $?$ & lost & \\
\hline scenica & Koch & 1872 & Habronestes & Australorena & $\mathrm{ZMH}$ & q \\
\hline scintillans & Pickard-Cambridge & 1869 & Storena & Chilumena & UMO & q \\
\hline spirafera & Koch & 1872 & Habronestes & Neostorena & lost & \\
\hline striatipes & Koch & 1872 & Habronestes & Habronestes & $\mathrm{ZMH}$ & 우 \\
\hline tetrica & Simon & 1908 & Storena & Storosa & $\mathrm{ZMB}$ & q \\
\hline toddi & Hickmann & 1944 & Storena & Habronestes & $\mathrm{AM}$ & $\sigma$ \\
\hline torosa & Simon & 1908 & Storena & Neostorena & $\mathrm{ZMB}$ & q \\
\hline tricolor & Simon & 1908 & Storena & ? & $\mathrm{ZMH}$ & juv \\
\hline variegata & Pickard-Cambridge & 1869 & Storena & $?$ & UMO & juv \\
\hline venatoria & Rainbow & 1914 & Neostorena & Neostorena & AM & juv \\
\hline zebra & Thorell & 1881 & Storena & Mallinella & MCSNG & 0 \\
\hline
\end{tabular}

Table 2. Leg measurements. F-femur; P-patella; T-tibia; Mt-metatarsus; $\mathrm{t}$-tarsus; Tot-total.

\begin{tabular}{clcccccr}
\hline & \multicolumn{1}{c}{$\mathbf{F}$} & $\mathbf{P}$ & $\mathbf{T}$ & $\mathbf{M t}$ & $\mathbf{t}$ & Tot \\
\hline Habronestes & bradleyi & (Pickard-Cambridge) & & & & \\
& I & 1.88 & 0.71 & 1.67 & 1.88 & $?$ & 6.14 \\
II & 1.88 & 0.71 & 1.50 & 1.88 & 1.38 & 7.35 \\
III & 1.88 & 0.71 & 1.50 & 1.75 & 1.41 & 7.25 \\
IV & 2.54 & 0.75 & 2.25 & 3.54 & 1.82 & 10.90 \\
Habronestes & grimwadei & (Dunn) & n.comb. & & & & \\
I & 1.83 & 0.58 & 1.50 & 1.71 & 1.29 & 6.91 \\
II & 1.88 & 0.62 & 1.42 & 1.79 & 1.29 & 7.00 \\
III & 1.63 & 0.57 & 1.34 & 1.85 & 1.32 & 6.71 \\
IV & 2.63 & 0.71 & 2.25 & 3.54 & 1.87 & 11.00
\end{tabular}


Table 2. Continued.

\begin{tabular}{|c|c|c|c|c|c|c|c|}
\hline & & $\mathbf{F}$ & $\mathbf{P}$ & $\mathbf{T}$ & Mt & $\mathbf{T}$ & Tot \\
\hline \multicolumn{8}{|c|}{ Habronestes toddi (Hickman) n.comb. } \\
\hline & $\mathrm{I}$ & 1.75 & 0.62 & 1.46 & 1.67 & 1.12 & 6.62 \\
\hline & II & 1.71 & 0.62 & 1.33 & 1.54 & 1.00 & 6.20 \\
\hline & III & 1.67 & 0.62 & 1.25 & 1.75 & 0.91 & 6.20 \\
\hline & IV & 2.04 & 0.58 & 1.63 & 2.38 & 1.21 & 7.84 \\
\hline \multicolumn{8}{|c|}{ Storosa tetrica (Simon) n.comb. } \\
\hline & I & 2.71 & 1.08 & 2.17 & 2.00 & 1.46 & 9.42 \\
\hline & II & 2.37 & 1.08 & 1.75 & 1.71 & 1.25 & 8.16 \\
\hline & III & 2.16 & 1.00 & 1.33 & 2.04 & 1.12 & 7.65 \\
\hline & IV & 2.75 & 1.16 & 2.08 & 3.08 & 1.50 & 10.57 \\
\hline \multicolumn{8}{|c|}{ Neostorena torosa (Simon) n.comb. } \\
\hline & I & 3.62 & 1.44 & 2.60 & 2.39 & 1.45 & 11.50 \\
\hline & II & 3.07 & 1.44 & 2.00 & 1.83 & 1.15 & 9.49 \\
\hline & III & 2.64 & 1.28 & 1.75 & 2.17 & 1.02 & 8.86 \\
\hline & IV & 3.58 & 1.62 & 2.56 & 3.24 & 1.28 & 12.28 \\
\hline \multicolumn{8}{|c|}{ Neostorena vituperata n.sp. } \\
\hline & I & 4.04 & 1.79 & 3.32 & 3.28 & 2.13 & 14.56 \\
\hline & II & 3.41 & 1.75 & 2.26 & 2.60 & 1.49 & 11.51 \\
\hline & III & 3.19 & 1.49 & 1.83 & 2.85 & 1.32 & 10.68 \\
\hline & IV & 4.17 & 1.70 & 2.98 & 4.38 & 1.62 & 14.85 \\
\hline \multicolumn{8}{|c|}{ Neostorena spirafera (Koch) n.comb. } \\
\hline & $\mathrm{I}$ & 2.00 & 0.85 & 1.51 & 1.45 & 0.95 & 6.76 \\
\hline & II & 1.80 & 0.85 & 1.25 & 1.30 & 0.90 & 6.10 \\
\hline & III & 1.60 & 0.85 & 1.00 & 1.50 & 0.75 & 5.70 \\
\hline & IV & 2.15 & 0.95 & 1.50 & 2.25 & 0.95 & 7.80 \\
\hline \multicolumn{8}{|c|}{ Mallinella zebra (Thorell) n.comb. ( $\left.\sigma^{\prime}\right)$} \\
\hline & I & 2.50 & 0.87 & 2.37 & 2.54 & 1.71 & 9.99 \\
\hline & II & 2.41 & 0.87 & 2.08 & 2.37 & 1.58 & 9.31 \\
\hline & III & 2.29 & 0.87 & 1.92 & 2.33 & 1.46 & 8.87 \\
\hline & IV & 2.71 & 0.92 & 2.50 & 3.46 & 2.21 & 11.80 \\
\hline \multicolumn{8}{|c|}{ Mallinella zebra (Thorell) n.comb. $(\stackrel{\circ}{)}$} \\
\hline & I & 2.04 & 0.77 & 1.83 & 1.92 & 1.61 & 8.17 \\
\hline & II & 2.00 & 0.77 & 1.49 & 1.83 & 1.28 & 7.37 \\
\hline & III & 1.92 & 0.81 & 1.53 & 2.00 & 1.28 & 7.54 \\
\hline & IV & 2.39 & 0.81 & 2.26 & 3.19 & 1.70 & 10.35 \\
\hline \multicolumn{8}{|c|}{ Nostera leucosema (Rainbow) n.comb. } \\
\hline & I & 2.50 & 0.87 & 2.08 & 2.21 & 1.42 & 9.08 \\
\hline & II & 2.13 & 0.96 & 1.63 & 1.87 & 1.21 & 7.80 \\
\hline & III & 1.96 & 0.96 & 1.47 & 1.83 & 1.00 & 7.22 \\
\hline & IV & 2.58 & 0.96 & 2.08 & 2.83 & 1.33 & 9.78 \\
\hline \multicolumn{8}{|c|}{ Nostera nadgee n.sp. ( $\sigma)$} \\
\hline & $\mathrm{I}$ & 2.37 & 0.93 & 1.71 & 1.54 & 1.03 & 7.58 \\
\hline & II & 1.92 & 0.82 & 1.34 & 1.44 & 0.93 & 6.45 \\
\hline & III & 1.83 & 0.89 & 0.87 & 1.71 & 1.03 & 6.33 \\
\hline & IV & 2.27 & 0.95 & 1.48 & 2.47 & 1.19 & 8.36 \\
\hline \multirow[t]{5}{*}{ Nostera $n$} & gee n.sp. (1 & Transit & Hill + ) & & & & \\
\hline & $\mathrm{I}$ & 1.58 & 0.89 & 1.28 & 0.98 & 0.68 & 5.41 \\
\hline & II & 1.45 & 0.77 & 0.98 & 1.94 & 0.60 & 5.74 \\
\hline & III & 1.28 & 0.77 & 0.85 & 1.11 & 0.68 & 4.69 \\
\hline & IV & 1.70 & 0.81 & 1.15 & 1.70 & 0.89 & 6.25 \\
\hline
\end{tabular}


Table 3. Leg spination; $d$-dorsal, disp-dispersed, not in obvious rows, $d w$-distal whorl, $p l$-prolateral, $r l$-retrolateral, $v$-ventral.

\begin{tabular}{|c|c|c|c|c|}
\hline & femur & patella & tibia & metatarus \\
\hline \multicolumn{5}{|c|}{ Habronestes bradleyi (Pickard-Cambridge) } \\
\hline I & $d 1-1$ & - & $d 1 p l 1 r l 1 v 1-1-2$ & $v 1-1-1-2$ \\
\hline II & $d 1-1$ & $p l 1$ & $d 1 p l 1 r l 1 v 1-1-2$ & $v 12$ \\
\hline III & $p l 1 d 3 * r l 1$ & $r l 1-1$ & $p l 1-1 d 3 * r l 3 * v 1-2-1-2$ & $24 d i s p$ \\
\hline IV & $p l 2 * d 3 * r l 1$ & $p l 1 r l 1$ & $p l 1 d 1-1 r l 1-1 v 2-2-1-2$ & 22 disp \\
\hline \multicolumn{5}{|c|}{ Habronestes grimwadei (Dunn) n.comb. } \\
\hline I & $p l 1 d 3 * v 6 *$ & $p l 1$ & $p l 2 * d 3 * v 1-1-2$ & $v 1-1-1-2$ \\
\hline II & $p l 1 d 3^{*} v 6^{*}$ & $p l 1$ & $p l 2 * d 3 * v 1-1-2$ & $v 1-1-1-2$ \\
\hline III & $d 3 * r l 1 v 3 *$ & $p l 1$ & $p l 2 * d 3 * v 2-2-2$ & 16 disp \\
\hline IV & $d 3 * r l 1 v 1$ & $p l 1$ & $p l 2 * d 3 * r l 1 v 2-2-2$ & 12 disp \\
\hline \multicolumn{5}{|c|}{ Habronestes toddi (Hickman) n.comb. } \\
\hline I & $p l 1 d 2 *$ & - & $p l 2 * d 2 * r l 1$ & $8 d i s p$ \\
\hline II & $p l 1 d 3^{*}$ & - & $p l 2 * d 2 * r l 1$ & 9 disp \\
\hline III & $p l 2 d 3 * r l 1$ & $d 5$ & $8 d i s p$ & 10 disp \\
\hline IV & $p l 1 d 3^{*}$ & $d 5$ & $8 d i s p$ & $10 d i s p$ \\
\hline \multicolumn{5}{|c|}{ Storosa tetrica (Simon) n.comb. } \\
\hline I & $d 1$ & - & $v 1-1-2$ & $v 2-2-2$ \\
\hline II & $d 1$ & - & $v 1-1-2$ & $v 2-2-2$ \\
\hline III & $d 1-1-2$ & $p l 1-1 r l 1$ & $p l 2 * d 3 * r l 2 * v 2-2-2$ & disp 16 \\
\hline IV & $d 3^{*}$ & $p l 2 * r l 1$ & $p l 2 * d 4 * r l 2 * v 2-2-2$ & disp 16 \\
\hline \multicolumn{5}{|c|}{ Neostorena torosa (Simon) n.comb. } \\
\hline I & $p l 1 d 2 *$ & - & $v 1-1-2$ & $v 2-2-3$ \\
\hline II & $p l 1 d 2 *$ & - & $v 1-1-2$ & $v 2-2-3$ \\
\hline III & $p l 1 d 3 * r l 1$ & $p l 2 d 1 r l 1$ & $p l 2 * d 3 * r l 2 * v 1-2-2$ & $10 d i s p \quad d w 6$ \\
\hline IV & $p l 1 d 3 * r l 1$ & $p l 2 d 1 r l 1$ & $p l 3 * d 3 * r l 3 * v 2-2-2$ & 12 disp $d w 6$ \\
\hline \multicolumn{5}{|c|}{ Neostorena vituperata n.sp. } \\
\hline I & $p l 1 d 2 *$ & - & $v 1-1-2$ & $v 1-2 d w 4$ \\
\hline II & $p l 1 d 2 *$ & - & - & $v 2 d w 4$ \\
\hline III & $p l 1 d 2 * r l 1$ & $p l 5 d 1 r l 1$ & $p l 2 * d 1-1-2 r l 2 * v 2-2-2$ & $8 d i s p \quad d w 6$ \\
\hline IV & $d 3 * r l 1$ & $p l 7 d 1 r l 1$ & $p l 2 * d 1-1-1-2 r l 2 v 2-1-2$ & $8 d i s p \quad d w 6$ \\
\hline \multicolumn{5}{|c|}{ Neostorena spirafera (Koch) n.comb. } \\
\hline I & $d 1$ & - & $v 1-1-2-1-1$ & $v 2-2 d w 3$ \\
\hline II & $d 1$ & - & $v 1-1-1$ & $v 2 d-2 w 3$ \\
\hline III & $d 1$ & $p l 2 d 1 r l 1$ & $p l 2 * d 3 * r l 2 * v 2-2-2$ & 7 disp $d w 6$ \\
\hline IV & $d 2 *$ & $p l 2 d 1 r l 1$ & $p l 2 * d 4 r l 2 v 2-1-2$ & $8 d i s p \quad d w 6$ \\
\hline \multicolumn{5}{|c|}{ Mallinella zebra (Thorell) n.comb. ( $\left.\sigma^{\prime}\right)$} \\
\hline I & $p l 2 * d 4 * r l 1$ & $p l 1$ & 11 disp & 12 disp \\
\hline II & $p l 2 * d 4 * r l 2 *$ & $p l 1$ & 11 disp & 9disp \\
\hline III & $p l 3 * d 4 * r l 1$ & $p l 1 r l 1$ & 12 disp & 17 disp \\
\hline IV & $p l 3 * d 4 * r l 1$ & $p l 1 r l 1$ & 14 disp & 19disp \\
\hline \multicolumn{5}{|c|}{ Mallinella zebra (Thorell) n.comb. (ং) } \\
\hline I & $p l 1 d 3^{*}$ & - & $p l 2 * v 2-1-2-2$ & $v 2-2-2$ \\
\hline II & $p l 1 d 3^{*}$ & $p l 1$ & $p l 2 * v 2-2-2$ & $v 2-2-2$ \\
\hline III & $p l 2 * 34 * r l 1$ & $p l 1 r l 1$ & $p l 2 * d 2 * r l 2 * v 2-1-1-2$ & $8 d i s p \quad d w 5$ \\
\hline IV & $p l 2 * d 4 * r l 1$ & $p l 1 r l 1$ & $p l 2 * d 2 * r l 2 * v 2-1-1-2$ & $10 d i s p \quad d w 6$ \\
\hline \multicolumn{5}{|c|}{ Nostera leucosema (Rainbow) n.comb. } \\
\hline I & $p l 1 d 2 *$ & - & $v 2-2$ & $v 2-2-2$ \\
\hline II & $p l 1 d 2 *$ & - & $p l 2 * v 1-2-2$ & $v 1-1-2$ \\
\hline III & $p l 2 * d 3 * r l 1$ & $p l 1 d 1 r l 1$ & $p l 2 * d 2 * r l 2 * v 2-2-2$ & $12 d i s p$ \\
\hline IV & $p l 2 * d 3 * r l 1$ & $p l 1 d 1 r l 1$ & $p l 2 * d 2 * r l 2 * v 2-2-2$ & 12 disp \\
\hline \multicolumn{5}{|c|}{ Nostera nadgee n.sp. $(\sigma)$} \\
\hline I & $p l 1 d 2 *$ & - & $v 2-2-2$ & $v 2-2-3$ \\
\hline II & $p l 1 d 2 *$ & - & $p l 2 * v 1-2-2$ & $v 2-2-3$ \\
\hline III & $p l 1 d 3 * r l 1$ & $p l 2 * d 1 r l 1$ & $p l 2 * d 3 * r l 2 * v 2-2-3$ & $10 d i s p \quad d w 6$ \\
\hline IV & $d 3^{*}$ & $p l 2 * d 1 r l 1$ & $p l 2 * d 3 * r l 2 * v 2-2-2$ & $10 d i s p \quad d w 6$ \\
\hline \multicolumn{5}{|c|}{ Nostera nadgee n.sp. (Transit Hill ${ }^{\text {) }}$} \\
\hline I & $d 1$ & - & - & $v 1-2-2$ \\
\hline II & $d 1$ & - & - & $v 2$ \\
\hline III & - & $p l 2 * d 1 r l 1$ & $p l 2 * d 3 * r l 2 * v 1-2-1$ & $8 d i s p \quad d w 6$ \\
\hline IV & $d 1$ & $p l 2 * d 1 r l 1$ & $p l 2 * d 3 * r l 2 * v 1-2-2$ & $10 d i s p \quad d w 6$ \\
\hline
\end{tabular}

